\title{
Explaining the persistence of low income and environmentally degrading land uses in the Brazilian Amazon
}

\author{
$\underline{\text { Rachael D. Garrett }}^{1}, \underline{\text { Toby A. Gardner }}^{2}$, Thiago Fonseca Morello $^{3}, \underline{\text { Sebastien Marchand }}^{4}, \underline{\text { Jos Barlow }}^{5}, \underline{\text { Driss Ezzine de Blas }}^{6}, \underline{\text { Joice }}$

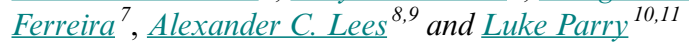

\begin{abstract}
Tropical forests continue to be plagued by the dual sustainability challenges of deforestation and rural poverty. We seek to understand why many of the farmers living in the Brazilian Amazon, home to the world's largest tropical agricultural-forest frontier, persist in agricultural activities associated with low incomes and high environmental damage. To answer this question, we assess the factors that shape the development and distribution of agricultural activities and farmer well-being in these frontiers. Our study utilizes a uniquely comprehensive social-ecological dataset from two regions in the eastern Brazilian Amazon and employs a novel conceptual framework that highlights the interdependencies between household attributes, agricultural activities, and well-being. We find that livestock production, which yields the lowest per hectare incomes, remains the most prevalent land use in remote areas, but many examples of high income fruit, horticulture, and staple crop production exist on small properties, particularly in peri-urban areas. The transition to more profitable land uses is limited by lagging supply chain infrastructure, social preferences, and the fact that income associated with land use activities is not a primary source of perceived life quality. Instead subjective well-being is more heavily influenced by the nonmonetary attributes of a rural lifestyle (safety, tranquility, community relations, etc.). We conclude that transitions away from low-income land uses in agricultural-forest frontiers of the Brazilian Amazon need not abandon a land-focused vision of development, but will require policies and programs that identify and discriminate households based on a broader set of household assets, cultural attributes, and aspirations than are traditionally applied. At a broader scale, access to distant markets for high value crops must be improved via investments in processing, storage, and marketing infrastructure.
\end{abstract}

Key Words: cattle; land use transitions; rural development; social capital; sustainable livelihoods

\section{INTRODUCTION}

Tropical forests are among the Earth's most important ecosystems and supply a diverse range of ecosystem services at local, regional, and global scales. Currently, these ecosystems are critically threatened by agricultural expansion for internationally traded commodities such as soybeans, palm oil, and beef (Hansen et al. 2013). As this multibillion dollar segment of the global economy has grown it has been accompanied by an increasing concentration of the tropical land base into fewer large farms (Pacheco 2012a, VanWey et al. 2013, Weinhold et al. 2013). Yet, a majority of the farmers in humid forests remain impoverished, often depending on subsistence agriculture for their livelihoods (Sunderlin et al. 2003).

For major development and conservation initiatives to deliver anticipated benefits to rainforest nations it is necessary to better understand the enabling conditions that can help catalyze pathways to improved well-being for all inhabitants of frontier landscapes, not just major producers of export commodities. This challenge is especially pronounced in the Brazilian Amazon, where agricultural exports have increased since 2005, yet rural income, education, and health remain well below the national average (Nepstad et al. 2014, Valentim and Garrett 2016).

The underlying causes of large-scale patterns of deforestation and agricultural expansion in the Brazilian Amazon, including changing global diets, domestic currency depreciation, state sponsored colonization, road building, agricultural subsidies, weak property rights, urbanization, and household demographics have been well documented (Moran 1993, Nepstad et al. 2001, Perz 2001, Geist and Lambin 2002, Richards et al. 2012, DeFries et al. 2013). Yet these analyses fall short of explaining why so many inhabitants of Amazonian agricultural-forest frontier landscapes remain engaged in agricultural activities that garner very low incomes and generate high levels of environmental damage, epitomized by extensive cattle-raising. This situation persists despite improvements in the enforcement of conservation policies in the region and a surge in voluntary environmental commitments within soybean and cattle commodity chains (Börner et al. 2015, Gibbs et al. 2015, 2016). Deforestation and pasture expansion in the Brazilian Amazon remain high in absolute terms (INPE 2016a), and forest clearance for cattle pastures remains the largest direct driver of forest loss on both small and large farms in the region (Pacheco 2012 $b$, INPE 2016b).

To address this research gap about the local factors influencing the persistence of low-income and unsustainable land use activities in the Amazon we ask three questions: (Q1) How does farm income differ across land uses? (Q2) How do household attributes, e.g., assets, background, accessibility, etc., shape land use choices? (Q3) How do land uses and their associated monetary

\footnotetext{
${ }^{1}$ Department of Earth and Environment, Boston University, Boston, USA, ${ }^{2}$ Stockholm Environment Institute, Stockholm, Sweden, ${ }^{3}$ Universidade Federal do ABC, Alameda da Universidade, São Bernardo do Campo, Brazil, ${ }^{4}$ CERDI/Université Clermont Auvergne, Clermont-Fd, France, ${ }^{5}$ Lancaster Environment Centre, Lancaster University, Lancaster, UK, ${ }^{6}$ Centre de Coopération Internationale en Recherche Agronomique pour le Développement (CIRAD). Campus International de Baillarguet, Montpellier, France, ${ }^{7}$ Embrapa Amazônia Oriental, Belém, Brazil, ${ }^{8}$ Division of Biology \& Conservation Ecology, School of Science and the Environment, Manchester Metropolitan University, Manchester, UK, ${ }^{9} \mathrm{Cornell}$ Lab of Ornithology, Cornell University, Ithaca, USA, ${ }^{10}$ Lancaster Environment Centre, Lancaster University, Lancaster UK, ${ }^{11}$ Universidade Federal do Pará (UFPA), Núcleo de Altos Estudos Amazônicos (NAEA), Belém, Brasil
} 
Fig. 1. Locations of case studies and properties sampled in the Eastern Amazon. Figure (a) Shows the case study region of greater Santarém, which includes the counties of Santarém, Belterra, and Mojui dos Campos. Figure (b) shows the case study region of Paragominas. In total we surveyed 499 properties (shown in grey).
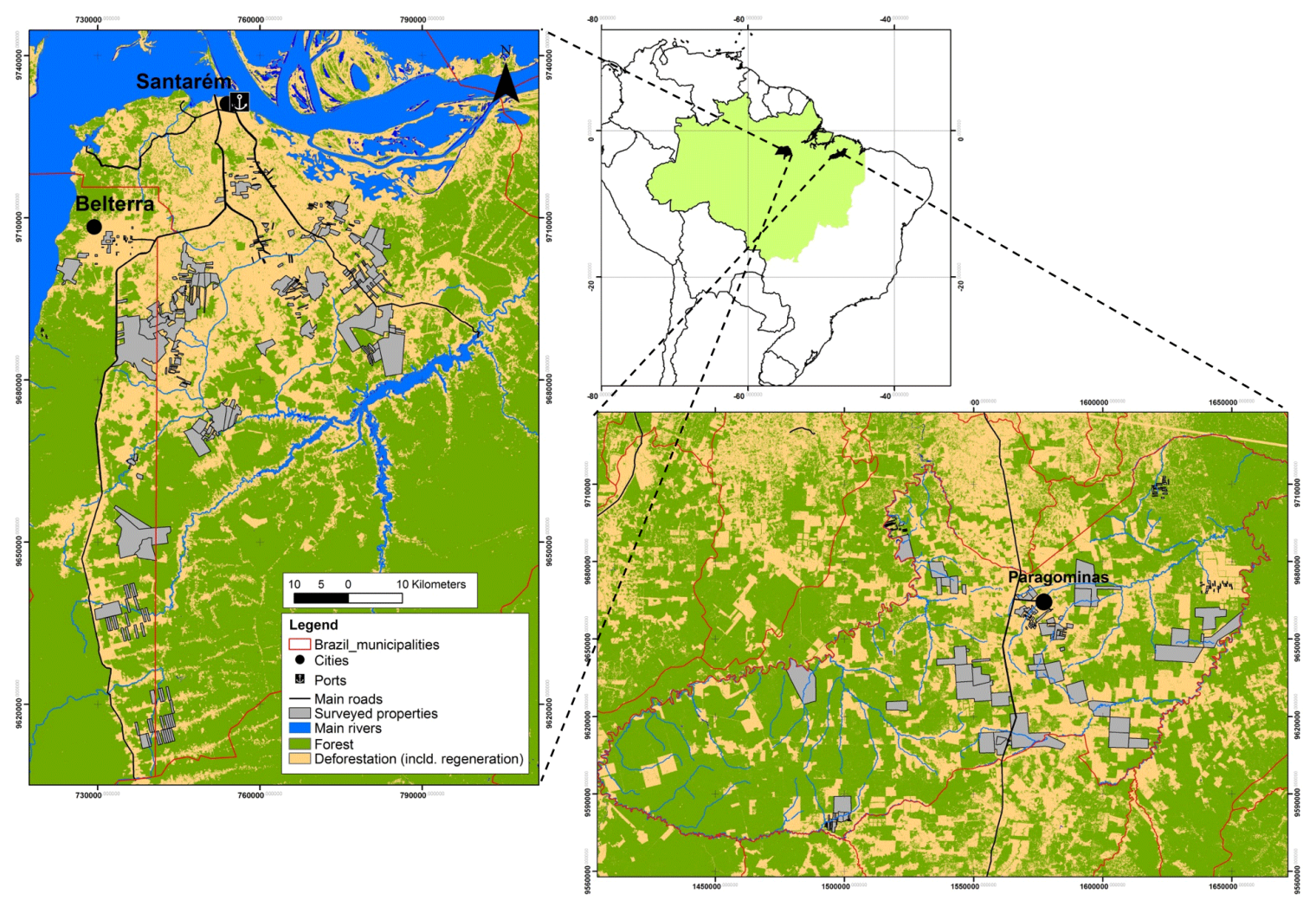

outcomes, together with underlying household attributes influence the well-being of rural households? By examining these interlinked questions, we seek to explain why existing environment and development policies based predominantly on traditional asset deficiencies (land, labor, and machinery) and monetary outcomes have been unable to catalyze wide-scale transformations toward higher income and potentially less environmentally damaging activities in the agricultural-forest frontiers of the Brazilian Amazon.

We apply these questions to two highly socially and environmentally heterogeneous regions in the eastern Brazilian Amazon (Fig. 1) that typify the close juxtaposition of export-led agriculture and persistent rural poverty in Amazonia in a dynamic forest frontier setting, yet possess unique environmental governance attributes (see A1.1 for more details on case selection). Using a comprehensive social and environmental dataset that was assembled by the Sustainable Amazon Network between 2010 and 2011 (http://www.redeamazoniasustentavel.org/; Gardner et al. 2013) we assess how a priori differences in household attributes determine patterns of land use and subjective well-being. In examining these relationships, we uncover possible explanations for why so few farmers are willing or able to adopt higher income, less environmentally damaging agricultural activities, in particular, why extensive cattle ranching remains so prevalent in Amazonia despite major transformations in rural livelihoods elsewhere in the tropics. We conclude by discussing how our findings may be used to improve the design of policies in Brazil, without necessarily abandoning a "land-focused" vision of development (Rigg 2006).

\section{BACKGROUND AND HYPOTHESES}

Existing theory and empirical analysis from agricultural economics and land change science suggest that current patterns of land use are the aggregate outcome of individual farmers acting to maximize their utility, given the assets they are endowed with (Officer and Halter 1968, Walker 2004). These studies typically focus on a narrow set of assets, including land, labor, and manufactured capital, concluding that the relative abundance of these key assets within a particular region plays a pivotal role in determining regional (and intra-household) land use choices. However, parallel research from development studies and political ecology has provided a deeper understanding of the context dependency of livelihood strategies, taking into account a broader range of household attributes, including gender, experiences, institutions, relationships, access, trust, obligations, norms, and institutions (Ribot and Peluso 2003, WinklerPrins and de Souza 2005, Ostrom 2009, Wollni and Brümmer 2012, Garrett et al. 2013, Rausch 2014). Because current household attributes and land use activities are heavily influenced by historical asset deficiencies and land use systems, as well as coevolving social and ecological systems, rural livelihood activities are often highly resilient to efforts aimed at changing behavior (Allison and Hobbs 2004, Wilcox 2017). 
A source of agreement between both literatures is that background processes of globalization, urbanization, migration, and infrastructure development are enhancing flows of ideas, money, and goods within and between rural and urban areas, leading to livelihoods that are increasingly pluralistic, engaging in both on and off-farm employment, and multilocal, occupying both urban and rural spaces simultaneously (Rigg 2006, Padoch et al. 2008, Greiner and Sakdapolrak 2013, Parry et al. 2014, Hecht et al. 2015). Consequently, changing urban diets, remittances, and nonmaterial flows between urban and rural areas may have a substantial impact on rural land use decisions. Migrants from cities settling in peri-urban regions may exhibit different attributes and aspirations than longstanding agrarian communities (Macdonald and Winklerprins 2014).

In looking beyond drivers of land use to examine the social consequences of agricultural activities, work on sustainable livelihoods has also underscored the importance of adopting a more nuanced conceptualization of the ways that agricultural activities may influence well-being (Scoones 1998, Bebbington 1999). Agricultural activities generate many benefits beyond income, such as lifestyle, spiritual value, social connections, and independence. Consequently, improved economic outcomes do not always translate into improved well-being and agricultural activities are often an end into themselves, not just a means to an end (Beckley 1995, Key and Roberts 2009, Knight et al. 2009). For this reason, a person's subjective well-being (one's perception of well-being measured as the response to questions regarding, for example, their level of happiness and satisfaction) can offer a more holistic measure of how well-off households are compared to that which is possible when only assessing monetized measures such as consumption, income, or savings (Diener and Seligman 2004). Moreover, any disconnect between income and well-being levels also serves to highlight the difficulties in understanding the drivers of land-use change when focusing exclusively on income measures.

The literature on cattle ranching, one of the most ubiquitous and persistent land uses in Brazil and in our study regions (Wilcox 2017), offers several specific hypotheses regarding the importance of household attributes and nonmonetary benefits for land use choices and well-being outcomes. First, extensive cattle ranching is thought to have low and less seasonal labor demands relative to most systems of crop production (Hecht 1993, Muchagata and Brown 2003), particularly nonmechanized fruit and horticulture production (Nepstad et al. 2001). This makes it an appealing land use in regions where labor is scarce, but land is abundant (Wilcox 2017). Second, in the context of volatile and uncertain land and currency markets, cattle ranching provides a low cost and low risk way to maintain control over a large land area and take advantage of speculative opportunities, while also building up a savings account, via the cattle themselves (Hecht 1993, Bowman et al. 2012, Campbell 2015). Third, cattle ownership has been long viewed as a status symbol in Latin American culture (Walker et al. 2000, Hoelle 2011). The prestige associated with cattle ranching in Amazonia can mask its low returns, creating an informational and cultural barrier to change (Hoelle 2011, Gomes et al. 2012).

Here we interweave these complementary research areas of land change science, political ecology, and sustainable livelihoods to provide a novel theoretical framework to advance current understanding of the development and distribution of agricultural activities and farmer well-being in the cattle dominated agricultural-forest frontiers typical of Amazonia (Fig. 2). Critically, our framework helps make explicit the degree to which rural well-being in these regions is influenced by myriad conditions beyond income, including nonmonetary benefits associated with agricultural activities and underlying household attributes, and the way in which these activities are, in turn, partly shaped and selected by differences in well-being. In doing so we seek to shed more light on the complex factors underpinning the persistence of low income and environmentally degrading land uses.

Fig. 2. Factors that influence the subjective well-being of rural households in relation to agricultural activities. A household's land use choices are influenced by a broad spectrum of assets and attributes. Productive assets, which are composed of natural, human, and manufactured capital, and underlying financial, social, and knowledge capital assets all influence a household's ability and incentives to pursue specific activities. Cultural backgrounds, physical location, and past agricultural activities in turn influence the ability of households to accumulate assets. Current land use and management choices determine farm and forest income, which in turn interacts with off-farm income, household attributes, and agricultural activities to influence subjective well-being.

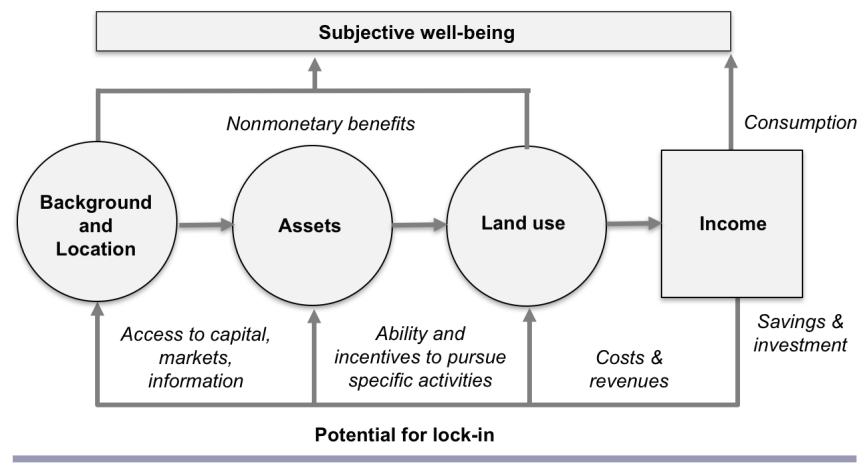

\section{METHODS}

\section{Data}

The Sustainable Amazon Network dataset collected ecological data from a stratified random sample of 367 transects distributed across 36 watersheds in the two regions of Santarem and Paragominas. These data were cocollected with socioeconomic survey data from up to 20 randomly selected rural properties within each watershed for a total of 623 households and 499 properties (several properties contained more than one household and some households had more than one property). All data were collected between 2010 and 2011. The ecological data at the transect scale include both land cover and soil characteristics. The socioeconomic data include details on land use and household assets, including origin, residence time, education, labor, tenure, credit access, group membership, and technical assistance. Farmers were asked to report details on land use for each property during the prior growing season (2009/2010) as well as 2006/2007. Respondents were asked to report information on their assets at 
Table 1. Distributions and descriptive statistics for all explanatory variables analyzed in this study.

\begin{tabular}{|c|c|c|c|c|c|c|}
\hline \multirow[t]{2}{*}{ Variable } & \multirow[t]{2}{*}{ Description } & \multirow[t]{2}{*}{ Scale } & \multicolumn{2}{|c|}{ Santarém } & \multicolumn{2}{|c|}{ Paragominas } \\
\hline & & & Mean & GINI & Mean & GINI \\
\hline \multicolumn{7}{|l|}{ Human capital } \\
\hline Labor & Number of people in household $>15$ years of age & $\mathrm{H}$ & $2.61 * * *$ & 0.45 & $1.53 * * *$ & 0.66 \\
\hline Education & Level of education (years) & $\mathrm{H}$ & $10.04^{*}$ & 0.22 & $8.79 *$ & 0.18 \\
\hline Female & Female head of household $(1,0)$ & $\mathrm{H}$ & $18 \%$ & 0.17 & $14 \%$ & 0.14 \\
\hline \multicolumn{7}{|l|}{ Natural capital } \\
\hline Property Size & Total property area, includes forest (ha) & $\mathrm{P}$ & $198 * * *$ & 0.83 & $640 * * *$ & 0.81 \\
\hline Farm Size & Property area in agriculture (ha) & $\mathrm{P}$ & $70^{* * *}$ & 0.85 & $406 * * *$ & 0.75 \\
\hline Water Access & Have access to dam or stream $(1,0)$ & $\mathrm{P}$ & $5 \%$ & 0.98 & $2 \%$ & 0.95 \\
\hline Forest Proportion & Proportion of total area in primary forest $(\%)$ & $\mathrm{P}$ & 20 & 0.71 & 23 & 0.59 \\
\hline \multicolumn{7}{|l|}{ Manufactured capital } \\
\hline Machinery & $\begin{array}{l}\text { Have access to machinery - includes both ownership and rental (1, } \\
0)\end{array}$ & $\mathrm{P}$ & $54 \%$ & 0.45 & $59 \%$ & 0.66 \\
\hline \multicolumn{7}{|l|}{ Financial capital } \\
\hline Govt. Cred & Have government credit $(1,0)$ & $\mathrm{P}$ & $23 \% *$ & 0.77 & $32 \% *$ & 0.68 \\
\hline \multicolumn{7}{|l|}{ Knowledge and Social capital } \\
\hline Govt. Assist & Have government tech assist $(1,0)$ & $\mathrm{P}$ & $16 \% *$ & 0.84 & $25 \% *$ & 0.75 \\
\hline Agric. Association & Social groups in which the farmer participates (\#) & $\mathrm{P}$ & 1.23 & 0.32 & 1.17 & 0.30 \\
\hline Title & Secure land ownership with definitive title $(1,0)$ & $\mathrm{P}$ & $33 \%$ & 0.67 & $36 \%$ & 0.64 \\
\hline \multicolumn{7}{|l|}{ Other Attributes } \\
\hline \multirow[t]{5}{*}{ Origin } & Origin - North $(1,0)$ & $\mathrm{H}$ & $49 \%$ & 0.51 & $49 \%$ & 0.51 \\
\hline & Origin - Northeast $(1,0)$ & $\mathrm{H}$ & $25 \% * *$ & 0.75 & $15 \% * *$ & 0.85 \\
\hline & Origin - Centerwest $(1,0)$ & $\mathrm{H}$ & $1 \%$ & 0.99 & $2 \%$ & 0.98 \\
\hline & Origin - South $(1,0)$ & $\mathrm{H}$ & $12 \% *$ & 0.88 & $3 \% *$ & 0.97 \\
\hline & Origin - Southeast $(1,0)$ & $\mathrm{H}$ & $1 \% * * *$ & 0.99 & $13 \% * * *$ & 0.87 \\
\hline Residence Time & Time that the household has resided at the property (years) & $\mathrm{H}$ & $24 * * *$ & 0.32 & $14 * * *$ & 0.38 \\
\hline Transport Time & Time get from property to the city center (hours) & $\mathrm{H}$ & 1.50 & 0.36 & 1.46 & 0.36 \\
\hline \multicolumn{7}{|l|}{ Expenditures and Income } \\
\hline Farm Expenditures & Total farm costs. US\$ & $\mathrm{P}$ & $10,641^{*}$ & 0.93 & $26,897^{*}$ & 0.89 \\
\hline Farm Income & Total farm product income. US\$ & $\mathrm{P}$ & $18,557^{*}$ & 0.94 & $38,623^{*}$ & 0.92 \\
\hline Forest Income & Total forest product income. US\$ & $\mathrm{P}$ & 40 & 0.57 & 5,010 & 0.59 \\
\hline Off-farm Income & $\begin{array}{l}\text { Total household income not derived from farming activities. } \\
\text { Includes wage labor, remittances, and conditional cash transfers. } \\
\text { US\$ }\end{array}$ & $\mathrm{H}$ & 3,308 & 0.52 & 3,135 & 0.56 \\
\hline Income Diversity & $\begin{array}{l}\text { Number of income sources (maximum of } 3 \text {, farm, forest, and off- } \\
\text { farm income) }\end{array}$ & $\mathrm{H}$ & 1.7 & 0.21 & 1.7 & 0.25 \\
\hline \multicolumn{7}{|c|}{ Tom } \\
\hline Life quality & $\begin{array}{l}\text { Reported satisfaction with "life in general in the region where you } \\
\text { live" } \\
\text { (1-3 - "poor," "okay," "good") }\end{array}$ & $\mathrm{H}$ & $2.7 * *$ & 0.09 & $2.5^{* *}$ & 0.11 \\
\hline Rural work quality & $\begin{array}{l}\text { Reported satisfaction with "opportunities to work locally" } \\
\text { (1-3 - "poor," "okay," good") }\end{array}$ & $\mathrm{H}$ & $1.4^{* * *}$ & 0.22 & $1.9 * * *$ & 0.23 \\
\hline Urban work quality & $\begin{array}{l}\text { Reported satisfaction with "opportunities to work in the city" } \\
\text { (1-3 - "poor," "okay," "good") }\end{array}$ & $\mathrm{H}$ & $1.6^{* *}$ & 0.24 & $1.8^{* *}$ & 0.24 \\
\hline Transportation & $\begin{array}{l}\text { Reported satisfaction with "access to transportation" } \\
\text { (1-3 - "poor," "okay," "good") }\end{array}$ & $\mathrm{H}$ & $2.3^{*}$ & 0.17 & $2.1^{*}$ & 0.22 \\
\hline Cultural activities & $\begin{array}{l}\text { Reported satisfaction with "cultural and sporting activities" } \\
\text { (1-3 - "poor," "okay," good") }\end{array}$ & $\mathrm{H}$ & $2.2 * * *$ & 0.18 & $2.0^{* *}$ & 0.21 \\
\hline Education & $\begin{array}{l}\text { Reported satisfaction with "access to quality schools" } \\
\text { (1-3 - "poor," "okay," "good") }\end{array}$ & $\mathrm{H}$ & 2.3 & 0.17 & 2.2 & 0.19 \\
\hline Health services & $\begin{array}{l}\text { Reported satisfaction with "health services" } \\
\text { (1-3 - "poor," "okay," "good") }\end{array}$ & $\mathrm{H}$ & $1.9^{* * *}$ & 0.21 & 1.6 & 0.23 \\
\hline Neighbors & $\begin{array}{l}\text { Reported satisfaction with "quality of neighbors" } \\
\text { (1-3 - "poor," "okay," "good") }\end{array}$ & $\mathrm{H}$ & 2.9 & 0.04 & 2.9 & 0.04 \\
\hline Security & $\begin{array}{l}\text { Reported satisfaction with "security" } \\
\text { (1-3 - "poor," "okay," "good") }\end{array}$ & $\mathrm{H}$ & $2.6 * * *$ & 0.13 & $2.4^{* * *}$ & 0.17 \\
\hline Migration probability & Would you sell your property and move to another region? & $\mathrm{H}$ & 0.11 & 0.89 & 0.15 & 0.85 \\
\hline
\end{tabular}

Notes: $\mathrm{P}=$ property level (\# of observations $=465$ total, 328 with full data), $\mathrm{H}=$ household level (\# of observations $=623$ aggregated to the property level by head of household). Statistics presented here are not mean or variance scaled. USD calculations made using exchange rate of 0.60 for $2010-2011$.

"indicates that the means within each region are significantly different at the $90 \%$ level using a two sided students t-test, $*=95 \%, * *=99 \%$, and $* * *=99.9 \%$. R package "stats" is used for this calculation. The GINI coefficient for each asset is calculated using R package "ineq." 
the household level for the current year (2010/2011). These data were joined by assigning the asset data from the principle household to land use data at the property level. Of the original 499 properties only 420 contained full data on all household assets.

\section{Variables and classifications}

The variables used in this analysis and their descriptive statistics are summarized in Table 1. Given a median property size of 50 hectares across both regions we removed two outliers $(>5000$ hectares) from the sample.

Each household-property was classified under a mutually exclusive land use category if more than $75 \%$ of the agricultural area of their property was allocated to that use. The land use categories include cattle (based on pasture area; $n=134$ ), staple crops (rice, beans, corn, and manioc; $n=135$ ), specialty crops (perennials and horticulture; $n=27)$, and soy $(n=21)$. Otherwise the household-property was classified as mixed-crop $(n=48)$ if more than $75 \%$ of the property was allocated to a combination of annuals, perennials, and horticulture or cattle-crop $(n=33)$ if the combined pasture and crop area exceeded $75 \%$ and it did not fall into any of the pre-existing categories. Properties that met the pasture area conditions to be classified as cattle or cattle-crop, but had zero head of cattle in 2006 or 2009 were classified as otherlivestock $(n=22)$. Properties that allocated more than $75 \%$ of their land to forest management $(n=2)$, including plantations, secondary, and primary forest, or derived more than $75 \%$ of their sales revenue from nontimber forest production $(n=7)$ were also excluded because of small sample sizes. The remaining 23 properties that did not meet any of the above criteria were omitted from the land use classification resulting in 420 observations. Given the very large farm sizes of cattle producers, pasture was the most expansive agricultural land use across the case study regions, occupying $73 \%$ of the agricultural area. Soy, staple, and specialty crops occupied $15 \%, 11 \%$, and $0.7 \%$ of the agricultural area, respectively. The land use distributions captured in our sample are representative of broader patterns within each municipality (IBGE 2006, 2016).

Farm, forest, and off-farm income are calculated separately and presented in U.S. dollars (US\$) using an average rate of exchange of 0.60 Brazilian Reais per US\$ during 2010 and 2011. Farm revenues include annual sales of agricultural products and animals. Farm expenditures include the operating costs of machinery, property maintenance costs, input costs, e.g. feed, fertilizer, and seeds, and wage labor costs. Missing prices for all products were obtained by market interviews. Net farm income for 2009/2010 is calculated by subtracting farm expenditures from farm revenues, except for cattle ranching, which also included costs and revenues over the three-year life-cycle of the existing herd and was then annualized, because many households were engaged only in cow-calf production or were in the process of rebuilding the herd for stocker (postweaning) production (see A2.1). In the models presented in the main text we do not include the costs of unpaid family labor because local agricultural wages do not reflect the true opportunity costs of this labor in poor agrarian regions (Bardhan 1979). Similarly, we do not include the value of products consumed at home as farm revenues because we did not collect data on this and using unsold products as a proxy for household consumption would likely overestimate the value of these products. Income from forest products is calculated as the sum of charcoal and nontimber forest products sales. Timber sales are excluded from the calculation because of a lack of reliable data on this activity and the widespread occurrence of illegal practices. Off-farm income is the sum of wages from offfarm employment, remittances, and conditional cash transfers. Given a mean per hectare income of US\$1200 we removed four outliers (< US\$10,000 or > US $\$ 20,000$ per hectare) from the sample.

\section{Analysis}

To assess how farm income differs across land uses (Q1) we used one-way Analysis of Variance (ANOVA) and Tukey's post-hoc tests. When significant differences in per hectare income among land uses were identified using an ANOVA test, we applied Tukey's post-hoc tests to assess differences between each pair of land uses.

To understand how property-household attributes influence land use (Q2) we used a multinomial logit model (Wooldridge 2010):

$$
y_{i j}=\alpha+\sum_{j=1}^{7} \beta_{j} Z_{i}+\gamma F+\varepsilon_{i j}
$$

where $i$ is a property-household, $j$ is a land use alternative, $y_{\mathrm{i}, \mathrm{j}}$ is the $\log [$ prob ( $i$ devoted to land use alternative $j$ )/prob ( $i$ devoted to comparison use), $Z_{\mathrm{i}}$ is a set of property-household attributes (Table 1 ), $F$ is a municipality dummy variable, and $\varepsilon_{i, j}$ is the error term. The theoretical model and justification for this model type are explained in A2.2. We do not include input prices as an additional determinant of land use because farmers were less able to recall these details (rather than overall costs) and where the data existed they were crude and exhibited a lack of variation within each study region. Differences in producer prices are captured by distance to town centers. We also exclude data on soil, slope, and elevation because it was sampled for a small number of transects within each watershed and does not adequately capture property level conditions. $\alpha, \beta$, and $\gamma$ are coefficients to be estimated and represent the effects on the logodds between the alternative $j$ and the base alternative. This model assumes that a property-household chooses its land use based on differences in perceived utility, maximizing utility among available alternatives. Because of the potential feedbacks between assets, we explored factor analysis but the Kaiser-Meyer-Olkin score of 0.42 and VIF scores $<1.5$ for all assets suggested that there was not enough correlation between assets to warrant such an approach (A3.1).

To understand the determinants of subjective well-being (Q3) we utilized an ordinal logistic (or ordered logit) model to examine the relative importance and potential causal relationships between subjective well-being and income, land use, and household attributes. Perceived life quality can be measured as the response to a single question about life satisfaction or as an index of responses regarding satisfaction with a variety of wellbeing attributes (Camfield 2006, Davey and Rato 2012). In this study we utilized a single direct response to the question "What is your evaluation of your life overall in the region where you live?" ( 1 = poor, 2 = okay, 3 = good $)$ as our dependent variable. We collected data on several other attributes of perceived well- 
being, which were all significantly correlated with perceived life quality, except for perceived quality of education services (A3.4). We concluded that none of these other variables better approximated perceived life quality than the single direct question about satisfaction with life overall so our well-being models focus on this metric. We also asked farmers to evaluate "opportunities for work locally" and "opportunities for work in the city," which we report in the results.

The ordinal logistic econometric model (Wooldridge 2010) is as follows:

$$
y_{i}=\alpha+\delta I_{i}+\eta L U_{i}+\beta Z_{i}+\gamma F+\varepsilon_{i}
$$

where $y_{\mathrm{i}}$ is the latent (unobserved) measure of the subjective wellbeing (perceived overall life quality) of a given propertyhousehold $i, L U_{\mathrm{i}}$ are a set of categorical variables indicating the land use activity each household-property pursues, $I_{i}$ represents farm, forest, and off-farm income as separate variables in model 1 and income diversity in model $2, Z_{i}$ and $F$ are the same as above, and $\varepsilon_{i}$ is the stochastic error term. More details on the theoretical model can be found in A2.3. We also examine the robustness of the results to alternate specifications where expenditures are also included as a determinant of well-being (A3.5). There was some multicollinearity in the model resulting from the association between assets and land use, but the VIF of all variables was $<1.9$.

\section{RESULTS}

Differences in farm income across land uses (Q1)

Specialty crop systems, i.e., perennials and horticulture, provided significantly higher per hectare returns $(+1300 \%)$ than livestock systems (Fig. 3; A3.2-A3.3), and $+200 \%$ higher returns than soy, staple, and mixed crop production. Staple crop systems were also associated with significantly higher per hectare returns than cattle, mixed cattle-crop, and other livestock systems. There was no significant difference in per hectare operating costs or labor costs across different land uses (One-way ANOVA comparing the effect of land use on per hectare costs, $\mathrm{p}=0.18$, $\mathrm{df}=6, \mathrm{~F}=1.5$ and labor costs, $\mathrm{p}=0.25$, $\mathrm{df}=6, \mathrm{~F}=1.3$ ).

The low per hectare incomes of cattle properties stemmed from low productivity ( 0.83 head of cattle per hectare), which in some cases did not even compensate the costs of production. The high income per hectare for specialty crops derived from the sale of citruses, pineapple, black pepper, and cucumber, which had high productivity and prices. Farm income was the largest source of income for households in our sample (Table 1), yet $75 \%$ of households earned less than US $\$ 10,000$ per year from agricultural activities.

\section{Influence of property-household attributes on land use (Q2)}

Land use choices were associated with myriad factors: traditional productive assets (land and machinery), financial capital (government credit), social and knowledge systems (government extension and membership in agricultural associations), region of origin, and proximity to the closest town (Table 2). Households with more off-farm income had the most diverse systems (mixed annual, horticulture, and perennial crops). Specialty, staple, and mixed cropping were significantly more common in small, periurban properties and among households who migrated from the south of Brazil (Fig. 4). Households that migrated from the
Fig. 3. Farm income (US\$/HA) by land use. Farm income is highest for households specializing in specialty crop production $($ mean income $=$ US $\$ 3304)$, followed by staple cropping (US\$1753), and lowest among households specializing in cattle (US\$372) and noncattle (US\$195) livestock production. Soy properties earn moderate incomes (US\$926). The box plots encompass the first and third quartiles, with the central bar depicting the median. Outliers greater than 1.5 times the interquartile range are suppressed. Means with the same lowercase letter at the top of the graph are not significantly different at the $95 \%$ level, based on post-hoc Tukey tests.

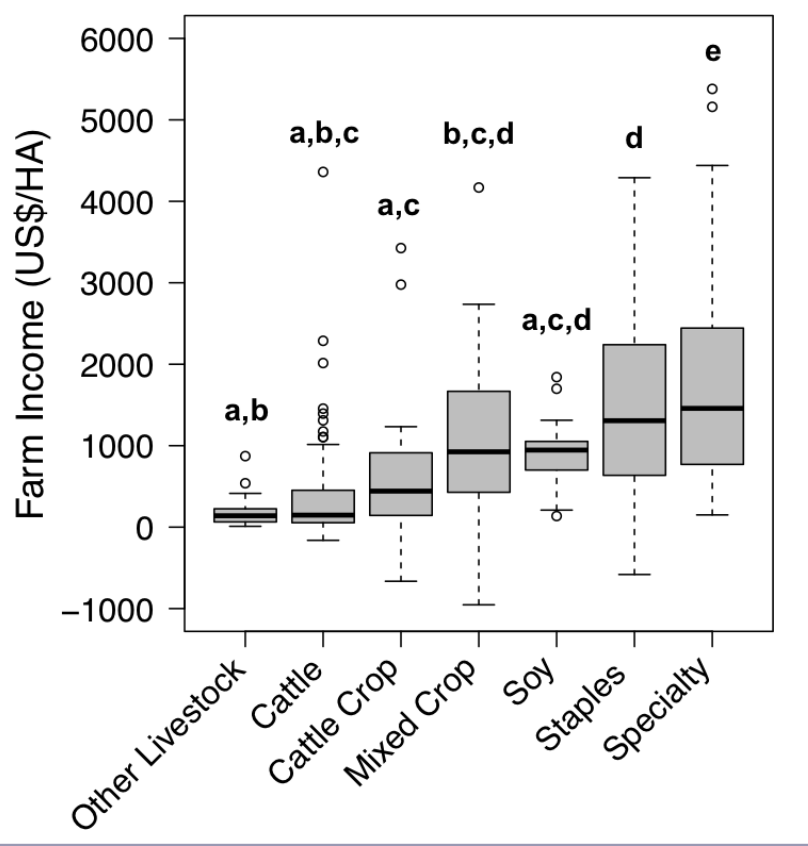

northeast and/or had on-average larger properties ( $\sim 300$ hectares of agricultural land, 800 hectares in total), located farther away from town, and lacked credit and machinery were the most likely to pursue cattle ranching. Households from the South of Brazil who had no machinery and did not receive government extension or belong to agricultural groups were more likely to choose other forms of livestock, e.g., chickens, pigs, or goats, over cattle. Access to machinery differentiated mixed crop-cattle properties from exclusively cattle properties, while access to government credit was substantially higher among soy properties.

\section{Determinants of subjective well-being (Q3)}

Subjective well-being (measured as perceived overall life quality) was consistently high among households in both study regions, but significantly higher in Santarém (Santarém: mean life quality $=2.7$ out of 3 , equivalent to "good," GINI $=0.09$; Paragominas: mean $=2.5$, GINI = 0.11; A3.4). Neither farm, forest, nor offfarm income or farm expenditures were associated with higher perceived life quality, despite being highly unequal within regions (Table 1). However, income diversity was positively associated with life quality (Table 3 ). Perceived life quality was higher among households that had less remaining forest on their property (a 
Table 2. Results for multinomial logit land use model.

\begin{tabular}{|c|c|c|c|c|c|c|}
\hline & \multicolumn{6}{|c|}{ Land Use } \\
\hline & $\begin{array}{c}\text { Cattle-Crop } \\
(\mathrm{n}=33)\end{array}$ & $\begin{array}{l}\text { Mixed Crop } \\
(\mathrm{n}=48)\end{array}$ & $\begin{array}{l}\text { Other Livestock } \\
\qquad(\mathrm{n}=22)\end{array}$ & $\begin{array}{c}\text { Soy } \\
\text { Crop } \\
(\mathrm{n}=21)\end{array}$ & $\begin{array}{c}\text { Specialty Crop } \\
(\mathrm{n}=27)\end{array}$ & $\begin{array}{c}\text { Staple } \\
\text { Crop } \\
(\mathrm{n}=135)\end{array}$ \\
\hline Off-farm Income & 0.07 & $0.67 *$ & -0.44 & -0.51 & -0.42 & -0.13 \\
\hline Family Labor & 0.32 & -0.01 & -0.61 & 0.4 & -0.08 & -0.28 \\
\hline Education & -0.05 & 0.05 & -0.02 & 0.9 & 0.17 & 0.02 \\
\hline Female & -0.07 & 0.54 & -0.24 & 17.14 & 0.33 & 0.68 \\
\hline Farm Size & -0.87 & $-2.15^{\dagger}$ & -4.19 & -0.34 & $-52.41 *$ & $-18.51 * * *$ \\
\hline Water Access & 1.25 & -20.68 & -18.71 & -18.18 & -19.91 & -21.12 \\
\hline Forest Proportion & 0.37 & 0.21 & 0.4 & -0.35 & 0.16 & 0.25 \\
\hline Machinery & $1.5^{*}$ & -0.36 & $-2.14 *$ & 16.97 & -0.87 & -0.43 \\
\hline Govt. Credit & 0.27 & -1.13 & 0.17 & 1.47 & 0.91 & -0.21 \\
\hline Govt. Extension & -0.34 & 0.68 & $-1.89^{\dagger}$ & -0.87 & -0.34 & 0.18 \\
\hline Agric. Associations & 0.21 & 0.11 & $-0.77^{\dagger}$ & -0.03 & -0.39 & $-0.47 *$ \\
\hline Definitive Land Title & -0.19 & 0.26 & 0.32 & 0.92 & 0.87 & 0.31 \\
\hline Origin - South & 1.68 & $2.83^{*}$ & $4.34 * *$ & $2.33^{\dagger}$ & $5.6 * * *$ & $2.55^{*}$ \\
\hline Origin - Northeast & -0.29 & $-0.99^{\dagger}$ & -1.23 & -16.39 & -0.37 & $-1.72 * * *$ \\
\hline Origin - Southeast & -23.14 & -22.77 & -20.39 & 0.83 & -18.8 & -0.46 \\
\hline Residence Time & 0.22 & 0.08 & 0.38 & -0.89 & 0.06 & 0.17 \\
\hline Distance to Town & $-0.04 *$ & $-0.06 * * *$ & 0.03 & -0.01 & $-0.08 * *$ & $-0.05 * * *$ \\
\hline Santarém & -0.72 & 0.12 & -0.96 & 0.09 & 0.2 & 0.29 \\
\hline Total \# of observations & \multicolumn{6}{|c|}{420} \\
\hline Reference case & \multicolumn{6}{|c|}{ "Cattle" $n=134$} \\
\hline McFadden $\mathrm{R}^{2}$ & \multicolumn{6}{|c|}{0.30} \\
\hline Log-Likelihood & \multicolumn{6}{|c|}{-360.51} \\
\hline Likelihood ratio test: chisq & \multicolumn{6}{|c|}{$362(\mathrm{p}$-value $=<2.22 \mathrm{e}-16)$} \\
\hline
\end{tabular}

Fig. 4. Land uses and their correlates. Selected significant results of the multinomial land use model are presented to demonstrate major differences in assets and attributes across households specializing in different land uses, i.e., $75 \%$ of their area is allocated to this land use. Cattle specialization is most common among households from the northeast and properties that are large and located farther away from markets. Properties specializing in noncattle livestock are characterized by a lack of machinery, extension, and membership in groups.

Specialization in cropping is most common among households from the south and properties that are small and located closer to markets. Agricultural group membership differentiates households that pursue specialty cropping versus staple cropping.

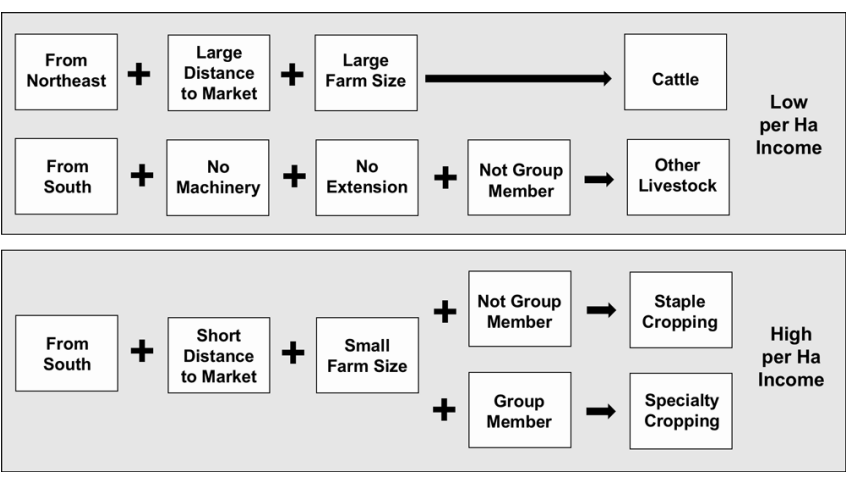

majority of the on-property forest reserves were secondary growth), and households pursuing mixed cropping (Table 3). When other satisfaction measures were not included, households who resided in their current location a longer time and lived closer to town had significantly higher perceived life quality (A3.5).

Perceptions of life quality were closely related to perceived safety and quality of access to transportation, rather than the quality of rural or urban work opportunities or access to services, which were ranked somewhere between "poor" and "okay" (A3.5). The perceived quality of one's neighbors was also closely related to perceived life quality (A3.4). Perceptions of the quality of rural and urban work opportunities were not significantly correlated with off-farm income.

\section{DISCUSSION}

Our study draws on diverse disciplinary perspectives to give novel insights into the continued persistence of low income and environmentally degrading land uses in rural Amazonia, the promise of specialty cropping on small farms in peri-urban regions, and the factors that contribute to perceived life quality in farming communities in these regions. We draw these conclusions by rigorously testing the causal linkages between household attributes, land use, and well-being and describing the broader-scale underlying economic and social processes influencing these linkages.

In contrast to recent papers highlighting the demise of smallholder farming and the increasingly pluralistic and multilocal nature of livelihoods in the rural south (Rigg 2006, Padoch et al. 2008, Greiner and Sakdapolrak 2013, Hecht et al. 
2015), we find that farmers in our study region are still primarily engaged in farming activities as their dominant source of income, and many successful examples of small-scale farming exist. However, the expansion of profitable land uses (horticulture and perennials) continues to be limited by lagging supply chains and the fact that agricultural income is not a primary source of perceived life quality. Instead, well-being in the study region is highly influenced by the nonmonetary outcomes associated with a rural lifestyle, including safety and good community relations, and the longer term economic and social benefits associated with the accumulation of land and cattle.

Table 3. Results for ordered logit subjective well-being model.

\begin{tabular}{|c|c|c|c|}
\hline Model & & I & II \\
\hline \multicolumn{4}{|c|}{ Other Satisfaction Measures } \\
\hline & Safety & $0.87 * * *$ & $0.91 * * *$ \\
\hline & Neighbors & $0.77^{*}$ & $0.69 *$ \\
\hline & Transportation & $0.44 *$ & $0.46^{*}$ \\
\hline \multicolumn{4}{|c|}{ Monetary Outcomes } \\
\hline & Farm Income & -0.39 & -- \\
\hline & Forest Income & 0.55 & -- \\
\hline & Off-farm Income & -0.11 & -- \\
\hline & Income Diversity & -- & $0.40^{\dagger}$ \\
\hline \multicolumn{4}{|c|}{ Land Use } \\
\hline & Cattle & -0.36 & -0.46 \\
\hline & Cattle-Crop & 0.41 & 0.27 \\
\hline & Mixed-Crop & $1.55^{*}$ & $1.24 *$ \\
\hline & Staples & -0.04 & -0.17 \\
\hline & Soy & 0.85 & 0.52 \\
\hline & Specialty & 0.14 & -0.01 \\
\hline \multicolumn{4}{|c|}{ Household Attributes } \\
\hline & Family Labor & -0.03 & -0.06 \\
\hline & Education & -0.12 & -0.11 \\
\hline & Female & -0.58 & $-0.63^{\dagger}$ \\
\hline & Any Machinery & 0.20 & 0.19 \\
\hline & Farm Size & 0.99 & 0.48 \\
\hline & Water Access & -0.46 & -0.22 \\
\hline & Forest Area & $-0.33^{\dagger}$ & $-0.33^{\dagger}$ \\
\hline & Govt. Credit & 0.07 & 0.00 \\
\hline & Govt. Extension & 0.22 & 0.23 \\
\hline & Agric. Association & 0.10 & 0.08 \\
\hline & $\begin{array}{l}\text { Definitive Land } \\
\text { Title }\end{array}$ & -0.28 & -0.36 \\
\hline & Origin - Northeast & 0.25 & 0.26 \\
\hline & Origin - South & -0.41 & -0.33 \\
\hline & Origin - Southeast & 0.65 & 0.78 \\
\hline & Residence Time & 0.22 & 0.16 \\
\hline & Distance to Town & -0.01 & -0.01 \\
\hline & Santarém & 0.39 & 0.44 \\
\hline & $\mathrm{AIC}$ & 470 & 462 \\
\hline & Log-likelihood & -203.96 & -203.45 \\
\hline
\end{tabular}

Notes: Results presented in the table are the regression coefficients resulting from equation 2 . The dependent variable is perceived life quality. Model I includes levels of income as an explanatory factor, while model II includes income diversity. $\mathrm{n}=328$;

${ }^{\dagger}$ indicates significance at the $90 \%$ level, $*=95 \%$ level, $* *=99 \%$, and

$* * *=99.9 \%$. Appendix Table 3.5 includes additional models.

\section{The persistence of low-income ranching in Amazonia}

Although much of land change science focuses on the assumption that land use activities are motivated by income maximization, the drivers of cattle ranching are recognized as being substantially more complex. The existing literature identifies low labor requirements, cost, and risk, as well as speculative and cultural value as factors influencing decisions to pursue cattle ranching. Yet, in our sample, the per hectare operating and labor costs for cattle properties were not statistically lower that other land uses, despite providing significantly lower farm incomes. Still, the onaverage larger farm sizes and very low per hectare incomes generated by cattle ranchers in our sample do support the narrative of ranching as an "unproductive profit-seeking" mechanism to maintain control over large areas while awaiting infrastructure developments and higher land prices (Hecht 1993, Bowman et al. 2012).

Yet, a majority of the cattle-focused properties in our sample do not have large agricultural areas $(<50$ hectares) and still engage in extensive cattle ranching, earning low per hectare incomes relative to cropping. For these smaller ranchers the cultural value of ranching and its social embeddedness (Hoelle 2011) is a more potent explanation of land use choices. Households that migrate from the northeast, who are often of Portuguese and Spanish descent, are significantly more likely to pursue ranching. In contrast households that migrate from the south, who are mainly of German and Italian origin, tend to pursue cropping or other forms of livestock production. Over $88 \%$ of cattle-focused properties participate in at least one agricultural association, which may increase the persistence of this land use by providing a sense of community and enabling better credit and market access.

\section{Specialty and mixed cropping as a pathway to higher incomes for} small farmers

Our study provides a glimpse into the promise of specialty and mixed cropping for increasing incomes on small farms. Citrus, black pepper, and vegetable production all provide up to 10 times higher returns than other land uses. Even staple cropping (bean, rice, and manioc production) provides significantly higher returns than cattle and mixed cattle-crop production. In contrast, soy production provides only moderate incomes and sustains itself through economies of scale.

The use of specialty, staple, and mixed cropping as the primary farm activity was most common on very small farms located in peri-urban areas among farmers who migrated from the south. Because of their background from a region where small farms and annual cropping are substantially more common and their location in relation to expanding urban markets, these farmers are likely characterized by an entirely different set of cultural preferences, experiences, and incentive structures. For example, earlier studies in the study region linked specialty crop production to an "economy of affection" among women (WinklerPrins 2002, WinklerPrins and De Souza 2005). Yet, unlike these studies, we find that fruit and horticulture products grown by households in our sample were largely sold, not gifted, and play a large role in generating income. Additionally, gender did not explain specialization in fruit or horticulture production.

Although specialty cropping may be a culturally appropriate and potentially economically appealing land use for small farmers located close to urban areas, it will likely remain limited in more remote regions of the Amazon because of inadequate processing, storage, and supply infrastructure and high costs of transportation (Dinham 2003, Pereira et al. 2016). Moreover, the 
high start-up costs associated with fruit and horticulture systems may be too high for farmers to afford or accept despite their longterm potential profitability (Simon 2008). Even in urban areas the expansion of specialty cropping is not without risks. For example, the application of pesticides and other chemical inputs will likely increase because fruit and vegetables are highly susceptible to pests (Dinham 2003, Simon 2008). If access to more distant markets remains limited, then increased local production of fruit and vegetables could outpace growth in demand, leading to a reduction in the price of these goods. On the other hand, such a reduction in the prices of fruits and vegetables could benefit the urban poor (Midmore and Jansen 2003).

\section{The complex determinants of subjective well-being}

Our analysis provides empirical evidence that income is not an adequate proxy for rural well-being in Amazonia (Macdonald and Winklerprins 2014), because neither on- or off-farm income were associated with higher perceived life quality. The disconnect between the income associated with land uses and its value to farmers may help explain why higher income land uses, specialty and staple cropping, are not associated with higher perceived life quality and why ranching, a low income land use, remains highly prevalent. Only mixed cropping, which falls somewhere in between ranching and specialty cropping in terms of abundance and profitability, investment costs, and risk, is associated with significantly higher perceived life quality. This implies that there are trade-offs between the nonmonetary benefits, long-term payouts, and annual incomes associated with different land uses.

Elsewhere in the rural south, studies have noted a process of "deagrarianization" and trends toward multilocality and pluriactivity among rural and urban areas, whereby farming activities have become less important to rural livelihoods (Rigg 2006, Greiner and Sakdapolrak 2013, Hecht et al. 2015). In our study region only $27 \%$ of households received income from off-farm employment and $7 \%$ received remittances. In fact, $65 \%$ of the offfarm income was from rural, not urban, employment opportunities, most commonly, housecleaning, as found elsewhere in Brazil (da Silva and Del Grossi 2001), though taxidriving, working on neighboring farms, and agribusiness services were also noted. Roughly $22 \%$ of households received some level of income from forest products, most commonly açai palm fruit and Brazil nuts, but there was little overlap between households with off-farm and forest income (only 14\% of households had farm, forest, and off-farm income). Nevertheless, those with higher income diversity did report higher perceived life quality, likely because diversity helps to reduce intra- and interannual income variability and risk (Ellis 2000, de Sherbinin et al. 2008). Income diversification into nonfarm activities among farm households is thought to be particularly appealing as wages in the nonfarm sector grow (Ellis 2000). However, opportunities for income diversification may be limited for families living in more remote regions of the Amazon (Jonasson and Helfand 2010), further cementing reliance on extensive cattle ranching.

Feeling secure and liking one's neighbors were strongly associated with higher perceived well-being. This suggests that a person's current condition relative to their past, is more important than any objective measure of their current condition, including income (Knight et al. 2009). For example, migrants from urban areas perceive countryside living as desirable because of its increased safety and calm compared with city life and focus less on the income generated from their agricultural activities (Macdonald and Winklerprins 2014).

Finally, differences in natural capital were also associated with differences in perceived well-being. Having a larger farm size and a larger proportion of the farm cleared (a smaller forest reserve) were both associated with higher perceived well-being, likely because they enable higher overall income and a greater range of land use and speculative possibilities, especially in the context of increasing restrictions on deforestation.

\section{Implications for improving environmental and agricultural conditions in the Brazilian Amazon}

The complexity and heterogeneity of the patterns, drivers, and outcomes of different land use in agricultural-forest frontier regions such as Amazonia highlights the urgent need for environmental and development policies that are better tailored toward the asset conditions and social preferences that influence the types of activities that farmers engage in, while also highlighting the pitfalls of focusing development and environment policies exclusively on monetary outcomes (Angelsen and Wunder 2003, Kingdon and Knight 2006, Eriksen and O'Brien 2007). Yet, most policy instruments aimed at smallholders in this region focus on the provision of subsidized inputs, credit, and insurance to address market failures and promote specific crops (Hazell et al. 2010), rather than building up the capacity of farmers and local communities to engage in more locally appropriate production practices (see A1.2 for discussion of rural development policy in Brazil).

To improve the design and targeting of alternative agricultural and development policies, we suggest that agricultural census data could be used to gather data and classify regions according to dominant household attributes and land use activities, though this suggestion is contrary to the direction planned for the next Brazilian Agricultural Census (Guimarães 2017). Enhanced diagnostic and planning tools are needed because households with larger, more remote properties need qualitatively different types of support than households residing in peri-urban areas with a small property. Farmers with a cultural preference for cattle and strong social capital need to be approached by extension agents and nongovernmental organizations with a different mindset and potential solutions than farmers with a long history of cropping. The former may indeed benefit from existing measures to provide targeted credit and extension to establish rotational grazing and irrigation to improve pasture quality (see A1.2). However, farmers with a preference for cropping, particularly those in more remote regions, would benefit more from larger-scale efforts to strengthen storage, processing, supply chains, and cooperative structures for high value crops. In particular, the profitability and attractiveness of crop production systems would be strengthened by directing more resources toward supply chain development for fruit and horticulture products, which generate $200-1600 \%$ more income per hectare than any other land use system in our study. Reaching regional or national markets will be critical to avoid local market saturation for these products.

Most successful cases of fruit export in the Amazon, including some fruits that now have global markets, have occurred in places where effective cooperatives have been created, backed by strong 
social cohesion and cultural identity (Piekielek 2010). Fostering these conditions is essential for any effort seeking to replicate such success stories. This more nuanced approach to detecting the attributes of households that define what is cultural appropriate and economically feasible would result in an improved regional typology of rural households beyond "small" or "family," as has been advocated by previous studies in the Global South (Reardon and Vosti 1995, Sunderlin et al. 2005, da Silva 2009, Medina et al. 2015).

In addition to improving the mechanisms by which household needs are assessed, policy makers should pay more attention to the diverse and changing social objectives of rural households (Pannell et al. 2006, Greiner et al. 2009, Key and Roberts 2009). Existing attempts at cattle intensification via pasture recuperation and crop integration throughout Brazil have been held back, in part, by a failure to appreciate the importance of cultural barriers and create knowledge systems that effectively communicate the financial viability and technical specifications of these systems (Gil et al. 2015). Similarly, throughout the tropics the success of organizations aiming to reduce fire usage has been limited by a failure to frame the problem in ways that make sense to local people (Carmenta et al. 2011, 2013, Clark et al. 2011). Thus, we emphasize here that future interventions to promote higher income, lower environmental degradation agricultural activities must focus on "local projects, not projects for locals" (Pokorny et al. 2005:438), harnessing the strengths of social networks and informal knowledge, rather than disseminating land use information via a top-down "technology transfer" approach.

Finally, we suggest that promoting win-win outcomes at the conservation-development nexus in Amazonia has proven elusive (Wunder 2001) because the development component has focused too heavily on income objectives. Agriculture continues to be an important part of rural livelihoods in the Brazilian Amazon, but not necessarily because of its income generating capacity. Although a baseline level of income is clearly necessary to meet certain objective needs (food, shelter, energy, etc.), other objectives can have a strong influence on land use decisions, such as safety and social status. Thus, policies based solely on raising incomes may lead to unintended environmental and social consequences, including rebound effects on deforestation and increased social inequality. Instead, it may be more fruitful to focus future development and environment programs on coupling conservation objectives with investments in household assets, particularly health and education, as well as novel mechanisms to promote social status based on the sustainability of land use activities.

\section{CONCLUSIONS}

Despite growing agricultural exports that have given rise to expanded market opportunities for some farmers, low incomes and environmental degradation remain pressing challenges in agricultural-forest frontiers throughout the world, particularly in regions dominated by cattle ranching. These challenges raise the question of how to transition more farmers away from lower income and environmentally damaging activities toward alternatives that both conserve nature and improve well-being, including potentially abandoning agriculture altogether. In our study region in the eastern Brazilian Amazon, farming remains the largest source of income amidst major changes in the surrounding region, including urbanization, migration, and wider globalization processes. In this context, we find that opportunities to generate higher income on small properties through specialty cropping exist, but are impeded by lagging supply chain infrastructure. Similarly, opportunities to improve the productivity of larger scale ranching through better management are now abundant, but slowed by a lack of machinery and the fact that generating high annual revenues is not the primary objective of cattle ranching as a land use. In both cases asset and access deficiencies and nonmonetary aspirations are mutually enforcing conditions that explain why lower income land uses persist in agricultural-forest frontiers.

Given the low quality of life in many urban areas and the relative affordability and tranquility of a rural lifestyle (Macdonald and Winklerprins 2014), it is worth exploring major amendments to the focus and targeting of agricultural policies and programs in the Brazilian Amazon, rather than abandoning land-based development altogether (e.g. as suggested by Rigg 2006 elsewhere). Our research suggests that past efforts to promote changes in land use in the Brazilian Amazon have been stymied by a mischaracterization of well-being in purely economic terms and a misunderstanding of the factors that motivate farmers' decisions including social context, nonmonetary objectives, and asset and access limitations. In the future, households should be identified and discriminated based on a broader set of attributes than are traditionally applied. Decision makers should work closely with local communities to frame "development" goals with a better understanding of households' nonmonetary objectives. Future research to aid these policy efforts in the Brazilian Amazon should focus more attention on the causal pathways and interdependencies between farmer assets, preferences, and activities as much as the endpoints of environmental degradation and development.

\section{Responses to this article can be read online at: http://www.ecologyandsociety.org/issues/responses. $\mathrm{php} / 9364$}

\footnotetext{
Acknowledgments:

We are grateful to William C. Clark for his insightful feedback on an earlier version of this manuscript. RDG was funded by the Giorgio Ruffolo Fellowship in Sustainability Science at Harvard University and the National Science Foundation Science, Engineering, and Education for Sustainability Program (Grant \#1415352) while undertaking this research. Support from Italy's Ministry for Environment, Land and Sea is gratefully acknowledged. SM was funded by the Université d'Auvergne (FUDA). We are also grateful to the following for financial support; Instituto Nacional de Ciência e Tecnologia - Biodiversidade e Uso da Terra na Amazônia (CNPq 574008/2008-0, and 400640/2012-0), Empresa Brasileira de Pesquisa Agropecuária - Embrapa (SEG: 02.08.06.005.00), the UK government Darwin Initiative (17-023), The Nature Conservancy, the UK Natural Environment Research Council (NERC) (NE/F01614X/1 and NE/G000816/1, NE/F015356/2; NE/l018123/1; NE/K016431/1), the Economic and Social Research Council (ESRC) (ES/K010018/1; ES/M011542/1), the
} 
Swedish Formas 2013-1571. We also thank the farmer and worker unions of Santarém, Belterra, Mojui dos Campos, and Paragominas and all collaborating private landowners for their support. The funders had no role in study design, data collection and analysis, decision to publish, or preparation of the manuscript.

\section{LITERATURE CITED}

Allison, H. E., and R. J. Hobbs. 2004. Resilience, adaptive capacity, and the "Lock-in Trap" of the Western Australian agricultural region. Ecology and society 9(1):3. http://dx.doi. org/10.5751/ES-00641-090103

Angelsen, A., and S. Wunder. 2003. Exploring the forest-poverty link: key concepts, issues and research implications. Center for International Forestry Research (CIFOR), Bogor, Indonesia.

Bardhan, P. K. 1979. Wages and unemployment in a poor agrarian economy: a theoretical and empirical analysis. Journal of Political Economy 87:479-500. http://dx.doi.org/10.1086/260774

Bebbington, A. 1999. Capitals and capabilities: a framework for analyzing peasant viability, rural livelihoods and poverty. World Development 27(12):2021-2044. http://dx.doi.org/10.1016/S0305-750X (99)00104-7

Beckley, T. M. 1995. Community stability and the relationship between economic and social well-being in forest-dependent communities. Society \& Natural Resources 8(3):261-266. http:// dx.doi.org/10.1080/08941929509380919

Börner, J., K. Kis-Katos, J. Hargrave, and K. König. 2015. Postcrackdown effectiveness of field-based forest law enforcement in the Brazilian Amazon. PLoS ONE 10(4):e0121544. http://dx.doi. org/10.1371/journal.pone.0121544

Bowman, M. S., B. S. Soares-Filho, F. D. Merry, D. C. Nepstad, H. Rodrigues, and O. T. Almeida. 2012. Persistence of cattle ranching in the Brazilian Amazon: a spatial analysis of the rationale for beef production. Land Use Policy 29(3):558-568. http://dx.doi.org/10.1016/j.landusepol.2011.09.009

Camfield, L. 2006. Why and how of understanding "subjective" well-being: exploratory work by the WeD group in four developing countries. Well-being in Developing Countries ESRC Research Group, Bath, UK.

Campbell, J. M. 2015. Conjuring property: speculation and environmental futures in the Brazilian Amazon. University of Washington Press, Seattle, Washington, USA.

Carmenta, R., L. Parry, A. Blackburn, S. Vermeylen, and J. Barlow. 2011. Understanding human-fire interactions in tropical forest regions: a case for interdisciplinary research across the natural and social sciences. Ecology and Society 16(1):53. http:// dx.doi.org/10.5751/ES-03950-160153

Carmenta, R., S. Vermeylen, L. Parry, and J. Barlow. 2013. Shifting cultivation and fire policy: insights from the Brazilian Amazon. Human Ecology 41(4):603-614. http://dx.doi.org/10.1007/ s10745-013-9600-1

Clark, W. C., T. P. Tomich, M. van Noordwijk, D. Guston, D. Catacutan, N. M. Dickson, and E. McNie. 2011. Boundary work for sustainable development: natural resource management at the Consultative Group on International Agricultural Research
(CGIAR). Proceedings of the National Academy of Sciences 113:4615-4622. http://dx.doi.org/10.1073/pnas.0900231108

da Silva, J. G. 2009. Zero hunger and territories of citizenship: promoting food security in Brazil's rural areas. Pages 367-374 in J. von Braun, R. Vargas Hill, R. Pandya-Lorch, editors. The poorest and hungry: assessments, analyses and actions. International Food Policy Research Institute, Washington, D.C., USA.

da Silva, J. G., and M. E. Del Grossi. 2001. Rural nonfarm employment and incomes in Brazil: patterns and evolution. World Development 29(3):443-453. http://dx.doi.org/10.1016/S0305-750X (00)00103-0

Davey, G., and R. Rato. 2012. Subjective wellbeing in China: a review. Journal of Happiness Studies 13(2):333-346. http://dx.doi. org/10.1007/s10902-011-9266-6

DeFries, R., M. Herold, L. Verchot, M. N. Macedo, and Y. Shimabukuro. 2013. Export-oriented deforestation in Mato Grosso: harbinger or exception for other tropical forests? Philosophical Transactions of the Royal Society B: Biological Sciences 368(1619). http://dx.doi.org/10.1098/rstb.2012.0173

de Sherbinin, A., L. K. VanWey, K. McSweeney, R. Aggarwal, A. Barbieri, S. Henry, L. M. Hunter, W. Twine, and R. Walker. 2008. Rural household demographics, livelihoods and the environment. Global Environmental Change 18(1):38-53. http:// dx.doi.org/10.1016/j.gloenvcha.2007.05.005

Diener, E., and M. E. P. Seligman. 2004. Beyond money: toward an economy of well-being. Psychological Science in the Public Interest 5(1):1-31. http://dx.doi.org/10.1111/j.0963-7214.2004.00501001. $\underline{\mathrm{x}}$

Dinham, B. 2003. Growing vegetables in developing countries for local urban populations and export markets: problems confronting small-scale producers. Pest Management Science 59 (5):575-582. http://dx.doi.org/10.1002/ps.654

Ellis, F. 2000. The determinants of rural livelihood diversification in developing countries. Journal of Agricultural Economics 51 (2):289-302. http://dx.doi.org/10.1111/j.1477-9552.2000.tb01229. $\underline{x}$

Eriksen, S. H., and K. O'Brien. 2007. Vulnerability, poverty and the need for sustainable adaptation measures. Climate Policy 7 (4):337-352. http://dx.doi.org/10.1080/14693062.2007.9685660

Gardner, T. A., J. Ferreira, J. Barlow, A. C. Lees, L. Parry, I. C. G. Vieira, E. Berenguer, R. Abramovay, A. Aleixo, C. Andretti, et al. 2013. A social and ecological assessment of tropical land uses at multiple scales: the Sustainable Amazon Network. Philosophical Transactions of the Royal Society B: Biological Sciences 368(1619):1-11. http://dx.doi.org/10.1098/rstb.2012.0166

Garrett, R. D., E. F. Lambin, and R. L. Naylor. 2013. The new economic geography of land use change: supply chain configurations and land use in the Brazilian Amazon. Land Use Policy 34:265-275. http://dx.doi.org/10.1016/j.landusepol.2013.03.011

Geist, H. J., and E. F. Lambin. 2002. Proximate causes and underlying driving forces of tropical deforestation. BioScience 52 (2):143-150. http://dx.doi.org/10.1641/0006-3568(2002)052[0143: PCAUDF]2.0.CO;2 
Gibbs, H. K., J. Munger, J. L'Roe, P. Barreto, R. Pereira, M. Christie, T. Amaral, and N. F. Walker. 2016. Did ranchers and slaughterhouses respond to zero-deforestation agreements in the Brazilian Amazon? Conservation Letters 9:32-42. http://dx.doi. org/10.1111/conl.12175

Gibbs, H. K., L. Rausch, J. Munger, I. Schelly, D. C. Morton, P. Noojipady, B. Soares-Filho, P. Barreto, L. Micol, and N. F. Walker. 2015. Brazil's soy moratorium. Science 347 (6220):377-378. http://dx.doi.org/10.1126/science.aaa0181

Gil, J., M. Siebold, and T. Berger. 2015. Adoption and development of integrated crop-livestock-forestry systems in Mato Grosso, Brazil. Agriculture, Ecosystems \& Environment 199:394-406. http://dx.doi.org/10.1016/j.agee.2014.10.008

Gomes, C. V. A., S. G. Perz, and J. M. Vadjunec. 2012. Convergence and contrasts in the adoption of cattle ranching: comparisons of smallholder agriculturalists and forest extractivists in the Amazon. Journal of Latin American Geography 11(1):99-120. http://dx.doi.org/10.1353/lag.2012.0018

Greiner, C., and P. Sakdapolrak. 2013. Translocality: concepts, applications and emerging research perspectives. Geography Compass 7(5):373-384. http://dx.doi.org/10.1111/gec3.12048

Greiner, R., L. Patterson, and O. Miller. 2009. Motivations, risk perceptions and adoption of conservation practices by farmers. Agricultural Systems 99(2-3):86-104. http://dx.doi.org/10.1016/j. agsy.2008.10.003

Guimarães, C. 2017. Censo agropecuário: que realidade do campo brasileiro se quer mostrar? Articulação Nacilonal de Agroecologia, Rio de Janeiro, Brasil.

Hansen, M. C., P. V Potapov, R. Moore, M. Hancher, S. A. Turubanova, A. Tyukavina, D. Thau, S. V Stehman, S. J. Goetz, T. R. Loveland, A. Kommareddy, A. Egorov, L. Chini, C. O. Justice, and J. R. G. Townshend. 2013. High-resolution global maps of 21st-century forest cover change. Science 342 (6160):850-853. http://dx.doi.org/10.1126/science.1244693

Hazell, P., C. Poulton, S. Wiggins, and A. Dorward. 2010. The future of small farms: trajectories and policy priorities. World Development 38(10):1349-1361. http://dx.doi.org/10.1016/j. worlddev.2009.06.012

Hecht, S. B. 1993. The logic of livestock and deforestation in Amazonia. BioScience 43(10):687-695. http://dx.doi.org/10.2307/1312340

Hecht, S., A. L. Yang, B. S. Basnett, C. Padoch, and N. L. Peluso. 2015. People in motion, forests in transition: trends in migration, urbanization, and remittances and their effects on tropical forests. Center for International Forestry Research (CIFOR), Bogor, Indonesia.

Hoelle, J. 2011. Convergence on cattle: political ecology, social group perceptions, and socioeconomic relationships in Acre, Brazil. Culture, Agriculture, Food and Environment 33(2):95-106. http://dx.doi.org/10.1111/j.2153-9561.2011.01053.x

Instituto Brasileiro de Geografia e Estatística (IBGE). 2006. Agriculture and livestock census. IBGE, Rio de Janeiro, Brasil.

Instituto Brasileiro de Geografia e Estatística (IBGE). 2016. Municipal agricultural production survey. IBGE, Rio de Janeiro, Brasil.
Instituto Nacional de Pesquisas Espaciais (INPE). 2016a. Projeto PRODES: Monitoramento da floresta Amazônica Brasileira por satélite. INPE, São José dos Campos, Brasil.

Instituto Nacional de Pesquisas Espaciais (INPE). $2016 b$. Dinâmica do uso e cobertura da terra no período de 10 anos nas áreas desflorestadas da Amazônia Legal Brasileira (Dinamics of land cover over 10 years in the deforeststed areas of the Brazilian Legal Amazon). INPE and Embrapa. INPE, São José dos Campos, Brasil.

Jonasson, E., and S. M. Helfand. 2010. How important are locational characteristics for rural non-agricultural employment? Lessons from Brazil. World Development 38(5):727-741. $\underline{\text { htp://dx. }}$ doi.org/10.1016/j.worlddev.2009.11.020

Key, N., and M. J. Roberts. 2009. Nonpecuniary benefits to farming: implications for supply response to decoupled payments. American Journal of Agricultural Economics 91(1):1-18. http://dx. doi.org/10.1111/j.1467-8276.2008.01180.x

Kingdon, G. G., and J. Knight. 2006. Subjective well-being poverty vs. income poverty and capabilities poverty? Journal of Development Studies 42(7):1199-1224. http://dx.doi. org/10.1080/00220380600884167

Knight, J., S. Lina, and R. Gunatilaka. 2009. Subjective well-being and its determinants in rural China. China Economic Review 20 (4):635-649. http://dx.doi.org/10.1016/j.chieco.2008.09.003

Macdonald, T., and A. M. G. A. Winklerprins. 2014. Searching for a better life: peri-urban migration in western Para State, Brazil. Geographical Review 104(3):294-309. http://dx.doi.org/10.1111/ j.1931-0846.2014.12027.x

Medina, G., C. Almeida, E. Novaes, J. Godar, and B. Pokorny. 2015. Development conditions for family farming: lessons from Brazil. World Development 74:386-396. http://dx.doi.org/10.1016/ j.worlddev.2015.05.023

Midmore, D. J., and H. G. P. Jansen. 2003. Supplying vegetables to Asian cities: is there a case for peri-urban production? Food Policy 28(1):13-27. http://dx.doi.org/10.1016/S0306-9192(02) 00067-2

Moran, E. F. 1993. Deforestation and land use in the Brazilian Amazon. Human Ecology 21(1):1-21. http://dx.doi.org/10.1007/ $\underline{\mathrm{BF} 00890069}$

Muchagata, M., and K. Brown. 2003. Cows, colonists and trees: rethinking cattle and environmental degradation in Brazilian Amazonia. Agricultural Systems 76(3):797-816. http://dx.doi. org/10.1016/S0308-521X(02)00015-X

Nepstad, D., G. Carvalho, A. C. Barros, A. Alencar, J. P. Capobianco, J. Bishop, P. Moutinho, P. Lefebvre, U. L. Silva Jr, and E. Prins. 2001. Road paving, fire regime feedbacks, and the future of Amazon forests. Forest Ecology and Management 154 (3):395-407. http://dx.doi.org/10.1016/S0378-1127(01)00511-4

Nepstad, D., D. McGrath, C. Stickler, A. Alencar, A. Azevedo, B. Swette, T. Bezerra, M. DiGiano, J. Shimada, R. S. da Motta, et al. 2014. Slowing Amazon deforestation through public policy and interventions in beef and soy supply chains. Science 344 (6188):1118-1123. http://dx.doi.org/10.1126/science.1248525 
Officer, R. R., and A. N. Halter. 1968. Utility analysis in a practical setting. American Journal of Agricultural Economics 50:257-277. http://dx.doi.org/10.2307/1237541

Ostrom, E. 2009. What is social capital? Pages 17-38 in V. O. Bartkus and J. H. Davis, editors. Social capital: reaching out, reaching in. Edward Elgar, Cheltenham, UK. http://dx.doi. org/10.4337/9781848445963.00010

Pacheco, P. 2012a. Soybean and oil palm expansion in South America: a review of main trends and implications. Center for International Forestry Research (CIFOR), Bogor, Indonesia.

Pacheco, P. 2012b. Actor and frontier types in the Brazilian Amazon: assessing interactions and outcomes associated with frontier expansion. Geoforum 43:864-874. http://dx.doi. org/10.1016/j.geoforum.2012.02.003

Padoch, C., E. Brondizio, S. Costa, M. Pinedo-Vasquez, R. R. Sears, and A. Siqueira. 2008. Urban forest and rural cities: multisited households, consumption patterns, and forest resources in Amazonia. Ecology and Society 13(2):2. http://dx.doi. org/10.5751/ES-02526-130202

Pannell, D. J., G. R. Marshall, N. Barr, A. Curtis, F. Vanclay, and R. Wilkinson. 2006. Understanding and promoting adoption of conservation practices by rural landholders. Animal Production Science 46(11):1407-1424. http://dx.doi.org/10.1071/EA05037

Parry, L., J. Barlow, and H. Pereira. 2014. Wildlife harvest and consumption in Amazonia's urbanized wilderness. Conservation Letters 7(6):565-574. http://dx.doi.org/10.1111/conl.12151

Pereira, R., C. S. Simmons, and R. Walker. 2016. Smallholders, agrarian reform, and globalization in the Brazilian Amazon: cattle versus the environment. Land 5(3):24. http://dx.doi. org/10.3390/land5030024

Perz, S. G. 2001. Household demographic factors as life cycle determinants of land use in the Amazon. Population Research and Policy Review 20(3):159-186. http://dx.doi.org/10.1023/A:1010658719768

Piekielek, J. 2010. Cooperativism and agroforestry in the eastern Amazon: the case of Tomé-Açu. Latin American Perspectives 37 (6):12-29. http://dx.doi.org/10.1177/0094582X10382097

Pokorny, B., G. Cayres, and W. Nunes. 2005. Participatory extension as basis for the work of rural extension services in the Amazon. Agriculture and Human Values 22(4):435-450. http://dx. doi.org/10.1007/s10460-005-3398-4

Rausch, L. 2014. Convergent agrarian frontiers in the settlement of Mato Grosso, Brazil. Historical Geography 42:276-297.

Reardon, T., and S. A. Vosti. 1995. Links between rural poverty and the environment in developing countries: asset categories and investment poverty. World Development 23(9):1495-1506. http:// dx.doi.org/10.1016/0305-750X(95)00061-G

Ribot, J. C., and N. L. Peluso. 2003. A theory of access. Rural Sociology 68:153-181. http://dx.doi.org/10.1111/j.1549-0831.2003. tb00133.x

Richards, P. D., R. J. Myers, S. M. Swinton, and R. T. Walker. 2012. Exchange rates, soybean supply response, and deforestation in South America. Global Environmental Change 22(2):454-462. http://dx.doi.org/10.1016/j.gloenvcha.2012.01.004
Rigg, J. 2006. Land, farming, livelihoods, and poverty: rethinking the links in the rural South. World Development 34(1):180-202. http://dx.doi.org/10.1016/j.worlddev.2005.07.015

Scoones, I. 1998. Sustainable rural livelihoods: a framework for analysis. Working Paper 72. Institute of Development Studies, Brighton, UK.

Simon, D. 2008. Urban environments: issues on the peri-urban fringe. Annual Review of Environment and Resources 33:167-185. http://dx.doi.org/10.1146/annurev.environ.33.021407.093240

Sunderlin, W. D., A. Angelsen, B. Belcher, P. Burgers, R. Nasi, L. Santoso, and S. Wunder. 2005. Livelihoods, forests, and conservation in developing countries: an overview. World Development 33(9):1383-1402. http://dx.doi.org/10.1016/j. worlddev.2004.10.004

Sunderlin, W. D., A. Angelsen, and S. Wunder. 2003. Forests and poverty alleviation. Pages 61-73 in State of the world's forests. UN Food and Agriculture Organization, Rome, Italy.

Valentim, J., and R. Garrett. 2016. Promoção do Bem-Estar dos Produtores Familiares com uso de Sistemas de Produção Agropecuários e Florestais de Baixo Carbono no Bioma Amazônia. Pages 73-98 in A. A. Azevedo, M. Campanili, and C. Pereira, editors. Caminhos para uma Agricultura Familiar sob Bases Ecológicas: Produzindo com Baixa Emissão de Carbono. Instituto de Pesquisa Ambiental da Amazônia, Belém, Brasil.

VanWey, L. K., S. Spera, R. de Sa, D. Mahr, and J. F. Mustard. 2013. Socioeconomic development and agricultural intensification in Mato Grosso. Philosophical Transactions of the Royal Society B: Biological Sciences 368(1619). http://dx.doi.org/10.1098/ rstb.2012.0168

Walker, R. 2004. Theorizing land-cover and land-use change: the case of tropical deforestation. International Regional Science Review 27(3):247-270. http://dx.doi.org/10.1177/0160017604266026

Walker, R., E. Moran, and L. Anselin. 2000. Deforestation and cattle ranching in the Brazilian Amazon: external capital and household processes. World Development 28(4):683-699. http:// dx.doi.org/10.1016/S0305-750X(99)00149-7

Weinhold, D., E. Killick, and E. J. Reis. 2013. Soybeans, poverty and Inequality in the Brazilian Amazon. World Development 52:132-143. http://dx.doi.org/10.1016/j.worlddev.2012.11.016

Wilcox, R. W. 2017. Cattle in the backlands: Mato Grosso and the evolution of ranching in the Brazilian tropics. University of Texas Press, Austin, Texas, USA.

WinklerPrins, A. M. G. A. 2002. House-lot gardens in Santarém, Pará, Brazil: linking rural with urban. Urban Ecosystems 6 (1-2):43-65.

WinklerPrins, A. M. G. A., and P. S. de Souza. 2005. Surviving the city: urban home gardens and the economy of affection in the Brazilian Amazon. Journal of Latin American Geography 4 (1):107-126. http://dx.doi.org/10.1353/lag.2005.0033

Wollni, M., and B. Brümmer. 2012. Productive efficiency of specialty and conventional coffee farmers in Costa Rica: accounting for technological heterogeneity and self-selection. Food Policy 37:67-76. http://dx.doi.org/10.1016/j.foodpol.2011.11.004 
Wooldridge, J. M. 2010. Econometric analysis of cross section and panel data. MIT Press, Cambridge, Massachusetts, USA.

Wunder, S. 2001. Poverty alleviation and tropical forests-what scope for synergies? World Development 29(11):1817-1833. http:// dx.doi.org/10.1016/S0305-750X(01)00070-5 
Appendix 1. Supplementary text on case study selection and policy landscape for Garrett et al. "Explaining the persistence of low income and environmentally degrading land uses in the Brazilian Amazon."

\section{A1.1 Case study selection}

Santarém and Paragominas were chosen for this study because they are fairly representative of the dynamic and diverse agricultural-forest frontiers found throughout the Brazilian Amazon (Valentim and Garrett, 2016). In these two regions export-oriented soy production has been introduced into a region long inhabited by staple, fruit, and horticulture producers and cattle ranchers, resulting in a wide array of agricultural activities. Both regions are relatively consolidated, with decreasing, but persistent rates of deforestation of primary vegetation. There is a mixture of private property and land in agrarian reform settlements and a wide range of farm sizes. Both regions have seen in-migration from all regions of Brazil and of farmers with very different socioeconomic backgrounds and assets. Yet Santarém and Paragominas have slightly different histories. Santarém, is a much older city, once the center of pre-Colombian civilization founded in 1661, while Paragominas was founded in 1959 (Gardner et al., 2013). Santarém is the site of a major soybean export terminal, while Paragominas is a hub for cattle ranching and an expanding silviculture sector. This diversity in backgrounds, assets, and land uses, both within and between regions, provides an ideal setting for statistical analysis.

Nevertheless, these two regions are unique in terms of the high level of attention they have received from environmental non-governmental institutions. In 2004 Santarém became an international icon of Amazonian deforestation for soybean production when the Cargill soybean terminal was built there (Greenpeace, 2006). A few years later Paragominas was placed near the top of the government's "blacklist" of municipalities with extremely high deforestation rates. Counties on the blacklist were prohibited from accessing agricultural credit until they reduced their deforestation levels. Both municipalities are now undertaking ambitious private-public partnerships to reduce deforestation for agriculture. In Santarém a partnership between the Nature Conservancy and Cargill has focused on improving the sustainability of soybean production and reducing deforestation (Garrett et al., 2013). The Município Verde (Green County) initiative in Paragominas has focused mainly on improving cattle production systems, particularly on large properties (Viana et al., 2016). The novel environmental governance initiatives present in these regions have engaged local farmers' groups and governments in a discussion around improved land use sustainability and aided our ability to conduct surveys in the region (Gardner et al., 2013). They have also created a community through which results of our analysis can be communicated. Thus, while both of these regions represent fairly unique cases in terms of their political context, they are important for study because they have substantial promise to achieve meaningful change in land use outcomes and may serve as a useful example for other regions in the Amazon.

\section{A1.2 Existing Brazilian agricultural and environmental policy}

The Brazilian government has invested heavily in the expansion and modernization of Brazilian agriculture since the 1970s through several different policy mechanisms. The bulk of support for producers stems from the National Rural Credit System, which provides low interest loans for all aspects of farm production including operation, storage, maintenance, and investment (Garrett and Rausch, 2015). Minimum price supports have been established for certain crops, such as soybean and corn, and the government will purchase grains from farmers at this minimum price when market prices plunge (Damico and Nassar, 2007). The government also supports agriculture through research and development led by the Brazilian Agricultural Research Corporation (EMBRAPA). 
There are a number of federal agricultural policies and programs designed specifically to support "family-farmers", extractive families and artisanal fishers in the country. Brazilian law 11,326 defines small family farmers as farmers who possess up to 400 hectares; use predominantly family labor in the economic activities of their farms; and rely primarily on farm activities for their household income. In 2006, family farmers accounted for $84 \%$ of the number and $24 \%$ of the area of the rural establishments (IBGE, 2006). The National Program for Strengthening Family Agriculture (PRONAF) provides subsidized rural credit for individual or collective projects that generate income for family farmers and agrarian reform settlers. The program has the lowest interest rates of any source of rural financing $(\sim 1 \%)$ in the country and covers both costs and investments in farm management and value added activities. PRONAF is linked to the technical assistance programs because upon being funded families are supposed to contact a state Rural Technical Assistance and Rural Extension agency to obtain a Declaration of Fitness for PRONAF (DAP). For beneficiaries of land reform and agrarian credit, the farmer must seek approval from the National Institute of Colonization and Agrarian Reform (INCRA) or the State Technical Unit (UTE). In 2010, the President of Brazil approved Law 12,188, which established the National Policy of Technical Advisory and Extension Services for Family Agriculture and Agrarian Reform (PNATER). The goal of this policy is to improve family farmers' food security and wellbeing, increase agricultural production, and conserve the environment through the provision of "participatory, multidisciplinary, equitable, and culturally appropriate" public advisory and extension services. This Law allows the government to make contracts with public, private and non-profit organizations accredited by the State Councils for Sustainable Rural Development, or a similar body for the provision of advisory and extension services (Brasil, 2010). In 2013, Brazil also passed Law 5,740 to create a National Agency of Technical Advisory and Extension Services (ANATER) with the goal of implementing the policies related to rural advisory and extension services for sustainable development. The government helps reduce risk for family farmers through the Insurance for Family Farmers (SEAF) program. SEAF provides insurance to farmers who adopt technologies that conserve natural resources on the farm and reduce their vulnerability to climatic fluctuations. Finally, Brazil's Program for the Sustainable Development of Rural Territories (PRONAT) creates new "Territories of Citizenship" to help define the needs of each territory. This policy mechanism is a promising vehicle for the improved asset classification system proposed in the main text. Despite the abundance of policies designed to help poor farmers, the reach of most programs is limited and few farmers outside of the South receive services.

Farms in the Legal Amazon region of Brazil are required by the Forest Code (Law 12,651) to set aside $80 \%$ of their forest area as a Legal [conservation] Reserve (although an amnesty is provided to many properties that cleared more than $80 \%$ of their original forest prior to 2008). Riparian areas and steep slopes must also be conserved in Permanent Preservation Areas. In the Cerrado portions of the Legal Amazon, the law requires 35\% of the land to be conserved in the Legal Reserve. In the Campos Gerais of the Legal Amazon and other biomes the law requires 20\% of the property to be protected. The Forest Code is enforced directly through fines for illegal activity, but also indirectly through restrictions on access to credit where producers are not in compliance (Garrett et al., 2013). In 2013 the Federal Government also launched a program requiring all farmers in the country to become registered in a Rural Environmental Registry (CAR), expanding what was once a program limited to states such as Pará and Mato Grosso. The goal of the program is to identify what steps need to be taken to bring properties into compliance with existing environmental regulations. Possession of a CAR will become a prerequisite for obtaining federally subsidized agricultural credit throughout the country, as it already is in the Amazon biome. 


\section{Appendix Literature Cited}

Brasil, 2010. Lei de Ater $n^{\circ}$ 12,188/2010. Brasília.

Chomitz, K.M., Gray, D.A., 1996. Roads, land use, and deforestation: A spatial model applied to Belize. World Bank Econ. Rev. 10, 487-512.

Damico, F.S., Nassar, A.M., 2007. Agricultural expansion and policies in Brazil, in: US Agricultural Policy and the 2007 Farm Bill. Woods Institute for the Environment at Stanford University, Stanford., pp. 75-96.

Gardner, T.A., Ferreira, J., Barlow, J., et al., 2013. A social and ecological assessment of tropical land uses at multiple scales: the Sustainable Amazon Network. Philos. Trans. R. Soc. B Biol. Sci. 368, 1-11. doi:10.1098/rstb.2012.0166

Garrett, R.D., Lambin, E.F., Naylor, R.L., 2013. The new economic geography of land use change: supply chain configurations and land use in the Brazilian Amazon. Land Use Policy 34, 265-275. doi:10.1016/j.landusepol.2013.03.011

Garrett, R.D., Rausch, L., 2015. Green for gold: social and ecological tradeoffs influencing the sustainability of the Brazilian soy industry. J. Peasant Stud. 43, 461-493. doi:10.1080/03066150.2015.1010077

Greenpeace, 2006. Eating up the amazon. Greenpeace.

IBGE, 2006. Agriculture and Livestock Census [WWW Document]. Braz. Inst. Geogr. Stat. URL http://sidra.ibge.gov.br

Li, M., Wu, J., Deng, X., 2013. Identifying drivers of land use change in China: A spatial multinomial logit model analysis. Land Econ. 89, 632-654.

McFadden, D., 1980. Econometric models for probabilistic choice among products. J. Bus. S13S29.

McKelvey, R.D., Zavoina, W., 1975. A statistical model for the analysis of ordinal level dependent variables. J. Math. Sociol. 4, 103-120.

Schuck, E.C., Nganje, W., Yantio, D., 2002. The role of land tenure and extension education in the adoption of slash and burn agriculture. Ecol. Econ. 43, 61-70.

Valentim, J., Garrett, R., 2016. Promoção do Bem-Estar dos Produtores Familiares com uso de Sistemas de Produção Agropecuários e Florestais de Baixo Carbono no Bioma Amazônia, in: Caminhos Para Uma Agricultura Familiar Sob Bases Ecológicas: Produzindo Com Baixa Emissão de Carbono. IPAM, pp. 73-98.

Viana, C., Coudel, E., Barlow, J., Ferreira, J., Gardner, T., Parry, L., 2016. How Does Hybrid Governance Emerge? Role of the elite in building a Green Municipality in the Eastern Brazilian Amazon. Environ. Policy Gov. 26, 337-350. doi:10.1002/eet.1720

Wooldridge, J.M., 2010. Econometric analysis of cross section and panel data. MIT Press, Cambridge, USA. 
Appendix 2. Supplementary text on methods for Garrett et al. "Explaining the persistence of low income and environmentally degrading land uses in the Brazilian Amazon."

\section{A2.1 Calculation of income and life cycle revenue stream for cattle}

Net income from cattle production was calculated using a net present value approach. We use this approach rather than a current snapshot based on cattle sales because a majority of cattle farms sold only $10 \%$ of their heard during 2010 and most herds were comprised largely of calves and juveniles, rather than adult cattle. The most common sale age for cattle in the region is 36 months, so most of the farms with high proportions of calves and juveniles and would not be selling their cattle for another one to two years. Our equation for this calculation is as follows:

$$
N P V=\mathbf{P}_{2010, \mathrm{i}} \times S_{2010, i}-C_{2010, i}+\frac{\mathbf{P}_{2011} \times S_{2011}-C_{2010}}{1+r}+\frac{\mathbf{P}_{2012} \times S_{2012}-C_{2010}}{(1+r)^{2}}
$$

where $\mathrm{r}$ is the interest rate, assumed to be $5 \%, \mathrm{P}_{\text {year, }}$ is the cattle sale price in 2010,2011 , and 2012 received by each property-household, $S_{2010, i}$ is the reported number of cattle sold in 2009 , $\mathrm{S}_{2011, \mathrm{i}}$ is the number of male and female juveniles reported on the property, and $\mathrm{S}_{2012, \mathrm{i}}$ is the number of male and female calves reported on the property. This calculation assumes that juveniles need on average 12 more months to mature before being sold and calves need 24 more months. It also assumes that all males and females are sold, rather than being kept for breeding. Total operating costs for the entire herd are assumed to be static across all three years $\left(\mathrm{C}_{2010}\right)$ because we lack any method to refine cost estimates in future periods. The price for each property-household in 2010 was obtained directly from the survey. Average local prices in 2010, 2011, and 2012 were obtained from local experts. We estimated prices received by each property-household in 2011 and 2012, by adding the \% increase or decrease in the average local market price for cattle in 2011 and 2012 to the prices received by each farm in 2010. Off-farm income includes remittances, wage labor, and conditional cash transfers. We do not deduct household expenditures.

\section{A2.2 Determinants of land use}

To understand how assets influence land use choices among our households we use a multinomial logit model (Wooldridge, 2010). We assume that farmers choose their land use strategies seeking to maximize utility (subjective wellbeing) from available alternatives. Net benefits, $B$, for the farmer $i$ using the alternative $j$ (i.e., one of the five land uses) are assumed to be a deterministic function of the set of conditioning assets $Z$ owned by the farmer (Table S1), so $B_{i j}(Z)$.

The expected utility $U$ of a given alternative $j$ is a function of the benefits of such assets, $U\left(B_{i j}(Z)\right)$, and can be decomposed into deterministic and stochastic elements, given by:

$$
U\left(\mathrm{~B}_{\mathrm{ij}}(\mathrm{Z})\right)=f_{i j}(\mathrm{Z})+\varepsilon_{\mathrm{ij}} \forall i=1, \cdots, N ; \forall j=1, \cdots, J,[1]
$$

where $f_{i j}(Z)$ is a deterministic function of farm assets, $\varepsilon_{i j}$ is a random variable representing unobserved farm attributes.

It is assumed that the farmer will continue to use alternative $j$, so long as the expected utility from $j$ is at least as high as another alternative $k$, such that: $U\left(B_{i j}(Z)\right) \geq U\left(B_{i k}(Z)\right) \geq 0$. Thus, among a sample of $N$ property-households, choosing among $j$ mutually exclusive land use 
strategies, the probability that a property-household $i$ selects alternative $j$ (over all other alternatives), conditioned to $\mathrm{Z}$, can be represented as:

$$
\begin{gathered}
\operatorname{Prob}(\mathrm{y}=\mathrm{j})=\operatorname{Prob}\left(U\left(\mathrm{~B}_{\mathrm{ij}}(\mathrm{Z}), \varepsilon_{\mathrm{ij}}\right)>U\left(\mathrm{~B}_{\mathrm{i} 0}(\mathrm{Z}), \varepsilon_{\mathrm{i} 0}\right)>, \cdots,>U\left(\mathrm{~B}_{\mathrm{iJ}-1}(\mathrm{Z}), \varepsilon_{\mathrm{ij}}\right)>\right. \\
\left.U\left(\mathrm{~B}_{\mathrm{iJ}}(\mathrm{Z}), \varepsilon_{\mathrm{ij}}\right)\right)[2]
\end{gathered}
$$

Equation (2) can be rewritten as:

$$
\operatorname{Prob}(\mathrm{y}=\mathrm{j})=\operatorname{Prob}\left(U\left(\mathrm{~B}_{\mathrm{ij}}(\mathrm{Z}), \varepsilon_{\mathrm{ij}}\right)>U\left(\mathrm{~B}_{\mathrm{ik}}(\mathrm{Z}), \varepsilon_{\mathrm{ik}}\right), \forall \mathrm{k}=1, \ldots, \mathrm{J}\right)
$$

It is generally assumed (McFadden, 1980; Wooldridge, 2010) that the last probability is a nonlinear function $G\left(\right.$.) of only $Z$ and the parameters of the linear approximation, $\beta_{j}, j=1, \ldots 7$, which can be subsumed to a J-column matrix, $\beta$, such that $P(y=j \mid Z)=G(Z, \beta)$. The multinomial logit model corresponds to the following specification for $G(Z, \beta)$ :

$$
G(\mathrm{Z}, \beta)=\left\{\begin{array}{c}
\frac{\exp \left(\mathrm{z} \beta_{\mathrm{j}}\right)}{1+\sum_{\mathrm{k}=1}^{7} \exp \left(\mathrm{Z} \beta_{\mathrm{k}}\right)}, \text { if } \mathrm{j}=2, \ldots, 7 \\
\frac{1}{1+\sum_{=1}^{7} \exp \left(\mathrm{Z} \beta_{\mathrm{k}}\right)}, \text { if } \mathrm{j}=1
\end{array}\right.
$$

So, $\sum_{j=1}^{5} \operatorname{Prob}(y=j \mid Z)=1$.

In operationalizing this framework we also include other household attributes $(\mathrm{C})$ and a regional fixed effect $(\mathrm{F})$ as control variables. All variables included in the model vary by individual $(i)$, not by alternative $(j)$.

The estimated model is:

$$
y_{i j}=\alpha+\sum_{j=1}^{7} \beta_{j} Z_{i}+\sum_{j=1}^{7} \lambda_{j} C_{i}+\gamma F+\varepsilon_{i j}[\mathbf{5}]
$$

where $y_{i j}$ is the $\log$ [prob ( $i$ devoted to $j$ )/prob ( $i$ devoted to the base alternative)]. That is to say that the coefficients of one land use strategy - in this case, "cattle" as the land use strategy - are normalized to zero. Thus, $\beta$ and $\gamma$ represent the effects on the log-odds between the alternative $j$ and the base alternative. Finally, estimation of equation 5 is best carried out by maximum likelihood (Wooldridge, 2010).

In choosing a multinomial logit approach over a binary choice model we considered the following issues. The binary choice model implies that the unordered response has only two outcomes (e.g., $\mathrm{Y}=1$ for cattle and $\mathrm{Y}=0$ for all other things). If there are other possible different alternatives alongside of the two retained, this model assumes that when an individual has to make the choice, he takes his decision without considering any other possible forms of land use, or, that is to say, that he considers that all other alternatives may be gathered into $\mathrm{Y}=0$. This can be challenged because the choice of $Y=1$ ("cattle") can be different regarding the nature of the other possible alternative. For instance, the choice of cattle is obviously different if the farmer has to choose between cattle and soy or between cattle and specialty crops. Therefore, the multinomial logit model is preferred to the binary choice model because several different alternatives are naturally at stake. In using the multinomial logit the independence of irrelevant alternatives assumption, i.e. the relative probabilities for any two alternatives depend only on the attributes of those two alternatives, may be questioned. If this assumption is not valid, the choice of the multinomial logit model should be challenged and a hierarchical model (e.g. a nested logit model) or a conditional probit model should be preferred. However, the multinomial logit model 
used in this paper is not sensitive to the IIA hypothesis because explanatory variables differ only across individuals and not across alternatives (Wooldridge, 2010 - p. 501-504). Finally, the multinomial logit model has been used in several prior studies to investigate the determinants of land use in the literature (See Chomitz and Gray, 1996; Li et al., 2013; Schuck et al., 2002 as examples).

\section{Determinants of subjective wellbeing}

To understand how assets, land use, and income influence subjective wellbeing (represented here as an ordinal factor variable - "life quality") we utilize an ordered logistic model (McKelvey and Zavoina, 1975):

$$
y_{i}^{*}=\alpha+\delta I_{i}+\eta L U_{i}+\beta Z_{i}+\lambda C_{i}+\gamma F+\varepsilon_{i},[6]
$$

where $y_{\mathrm{i}}{ }^{*}$ is a latent (unobserved) measure of the subjective wellbeing of a given propertyhousehold $i, L U_{\mathrm{i}}$ is a set of categorical variables indicating the land use each household-property $i$ pursues in terms of land uses, $I_{i}$ represents total farm income and off-farm income as separate variables, $Z_{i}, C_{i}$, and $F$ are the same set of variables as above, and $\varepsilon_{i}$ is the stochastic error term.

The relationship between observed life quality, Y, and the latent variable behind the reported levels (the true continuous measure of subjective wellbeing), $\mathrm{Y}^{*}$, is as follows (Wooldridge, 2010):

If $\mathrm{Y}^{*} \leq \delta_{1}$, then $\mathrm{y}=1$

If $\delta_{1}<\mathrm{Y}^{*} \leq \delta_{2}$, then $\mathrm{y}=2$

If $\mathrm{Y}^{*}>\delta_{2}$, then $\mathrm{y}=3$

With $\delta_{1}$ and $\delta_{2}$ being the cut points on the latent variable behind the choice of life quality levels. Thus the probabilities for each of the observed ordinal responses $(1,2,3)$ for low life quality, moderate life quality, and high life quality, respectively, will be given as:

$$
\begin{aligned}
& \mathrm{P}(\mathrm{Y}=1)=\mathrm{P}\left(\mathrm{Y}^{*} \leq \delta_{1}\right)=\mathrm{P}\left(\boldsymbol{\beta}^{\prime} \mathrm{x}+\boldsymbol{\varepsilon}^{*} \leq \delta_{1}\right)=\mathrm{F}\left(\delta_{1}-\boldsymbol{\beta}^{\prime} \mathrm{x}\right) \\
& \mathrm{P}(\mathrm{Y}=2)=\mathrm{P}\left(\delta_{1}<\mathrm{Y}^{*} \leq \delta_{2}\right)=\mathrm{F}\left(\boldsymbol{\delta}_{2}-\boldsymbol{\beta}{ }^{\prime} \mathrm{x}\right)-\mathrm{F}\left(\delta_{1}-\boldsymbol{\beta}^{\prime} \mathrm{x}\right) \\
& \mathrm{P}(\mathrm{Y}=3)=1-\mathrm{F}\left(\boldsymbol{\delta}_{2}-\boldsymbol{\beta}^{\prime} \mathrm{x}\right)
\end{aligned}
$$

where $F$ is the cumulative distribution function (CDF) for the stochastic error term $\varepsilon$, assumed to follow a logistic function. The unobservable cut points $\left(\delta_{1}\right.$ and $\left.\delta_{2}\right)$ are estimated together with other parameters in the model. If an intercept is appended to the model, it automatically plays the role of the cut point. This model assumes that the relationship between each pair of life quality outcome groups (e.g. 1 to 2 and 2 to 3 ) is the same. 
Appendix 3. Supplementary tables for Garrett et al. "Explaining the persistence of low income and environmentally degrading land uses in the Brazilian Amazon."

Table A3.1: Correlation table for all explanatory variables analyzed in this study.

\begin{tabular}{|c|c|c|c|c|c|c|}
\hline & Labor & Educ. & Female & Area & Water & Forest $\%$ \\
\hline Labor & 1 & $0.17 * * *$ & 0.08 & -0.08 & $0.13 * * *$ & 0.07 \\
\hline Education & $0.17 * * *$ & 1 & 0.07 & 0.02 & -0.04 & 0.01 \\
\hline Female & 0.08 & 0.07 & 1 & -0.07 & -0.08 & -0.01 \\
\hline Area & -0.08 & 0.02 & -0.07 & 1 & 0.04 & $0.12 * *$ \\
\hline Water & $0.13 * * *$ & -0.04 & -0.08 & 0.04 & 1 & $0.12 *$ \\
\hline Forest \% & 0.07 & 0.01 & -0.01 & $0.12 * *$ & $0.12 *$ & 1 \\
\hline Machine & 0.01 & $-0.15 * * *$ & $-0.13 * *$ & $0.16^{* * *}$ & 0.07 & $0.15 * * *$ \\
\hline Govt. Credit & 0.04 & -0.04 & $-0.13 * *$ & $0.12 *$ & 0.05 & $0.15^{* * * *}$ \\
\hline Govt. Assist & 0.06 & -0.01 & 0.01 & -0.08 & 0.00 & -0.02 \\
\hline Ag. Association & $0.12 *$ & 0.07 & $0.14 * *$ & -0.06 & 0.00 & 0.06 \\
\hline Defn. Title & 0.03 & $-0.11^{*}$ & -0.02 & $0.21^{* * *}$ & 0.08 & $0.13 * *$ \\
\hline Origin-North & 0.03 & 0.04 & -0.05 & $-0.13^{* *}$ & 0.01 & -0.06 \\
\hline Origin-Northeast & -0.04 & -0.04 & -0.09 & -0.06 & 0.02 & $-0.11 *$ \\
\hline Origin-South & $0.1^{*}$ & 0.06 & $-0.09 *$ & 0.02 & -0.06 & $0.18^{* * * *}$ \\
\hline Origin-Southeast & -0.02 & $-0.13 * *$ & -0.09 & $0.22 * * *$ & 0.00 & 0.05 \\
\hline Residence Time & $0.15^{* * *}$ & -0.06 & $0.12 *$ & -0.06 & $0.11 *$ & -0.07 \\
\hline Distance to Town & -0.04 & 0.00 & -0.07 & -0.01 & 0.03 & $0.39 * * *$ \\
\hline
\end{tabular}

Notes: Results represent Spearman's rank correlation coefficients. * indicates a significant bivariate correlation at the $95 \%$ level, $* *=99 \%$, and $* * *=99.9 \%$.

Table A3.1: Correlation table for all explanatory variables analyzed in this study, ctd.

\begin{tabular}{lccccc}
\hline & Machine & $\begin{array}{c}\text { Govt. } \\
\text { Credit }\end{array}$ & Govt. Assist & $\begin{array}{c}\text { Ag. } \\
\text { Association }\end{array}$ & $\begin{array}{c}\text { Definitive } \\
\text { Title }\end{array}$ \\
\hline Labor & 0.01 & 0.04 & 0.06 & $0.12^{*}$ & 0.03 \\
Education & $-0.15^{* * *}$ & -0.04 & -0.01 & 0.07 & $-0.11^{*}$ \\
Female & $-0.13^{* *}$ & $-0.13^{* *}$ & 0.01 & $0.14^{* *}$ & -0.02 \\
Area & $0.16^{* * *}$ & $0.12^{*}$ & -0.08 & -0.06 & $0.21^{* * *}$ \\
Water & 0.07 & 0.05 & 0.00 & 0.00 & 0.08 \\
Forest $\%$ & $0.15^{* * *}$ & $0.15^{* * *}$ & -0.02 & 0.06 & $0.13^{* *}$ \\
Machine & 1 & $0.37^{* * *}$ & 0.04 & $0.13^{* * *}$ & $0.18^{* * *}$ \\
Govt. Credit & $0.37^{* * *}$ & 1 & $0.29^{* * *}$ & $0.25^{* * *}$ & $0.15^{* * *}$ \\
Govt. Assist & 0.04 & $0.29^{* * *}$ & 1 & $0.23^{* * *}$ & -0.03 \\
Ag. Association & $0.13^{* * *}$ & $0.25^{* * *}$ & $0.23^{* * *}$ & 1 & -0.01 \\
Defn. Title & $0.18^{* * *}$ & $0.15^{* * *}$ & -0.03 & -0.01 & 1 \\
Origin-North & -0.07 & -0.03 & 0.08 & $0.1 *$ & -0.03 \\
Origin-Northeast & 0.03 & 0 & -0.05 & -0.08 & $-0.30^{* * *}$ \\
Origin-South & -0.04 & -0.05 & $0.09 *$ & 0.03 & $-0.15^{* *}$ \\
Origin-Southeast & $-0.13^{* *}$ & -0.04 & $-0.09^{*}$ & 0.03 & $0.38^{* * *}$ \\
Residence Time & -0.02 & 0.08 & 0 & $0.21^{* * *}$ & $0.28^{* * *}$ \\
Distance to Town & 0.04 & $0.15^{* * *}$ & $0.27^{* * *}$ & 0.06 & -0.09 \\
\hline Not Resuls & res & Sp & &
\end{tabular}

Notes: Results represent Spearman's rank correlation coefficients. * indicates a significant bivariate correlation at the $95 \%$ level, $* *=99 \%$, and $* * *=99.9 \%$. 
Table A3.1: Correlation table for all explanatory variables analyzed in this study, ctd.

\begin{tabular}{lcccccc}
\hline & $\begin{array}{c}\text { Origin- } \\
\text { North }\end{array}$ & $\begin{array}{c}\text { Origin- } \\
\text { Northeast }\end{array}$ & $\begin{array}{c}\text { Origin- } \\
\text { South }\end{array}$ & $\begin{array}{c}\text { Origin- } \\
\text { Southeast }\end{array}$ & $\begin{array}{c}\text { Residence } \\
\text { Time }\end{array}$ & $\begin{array}{c}\text { Distance to } \\
\text { Town }\end{array}$ \\
\hline Labor & 0.03 & -0.04 & $0.1^{*}$ & -0.02 & $0.15^{* * *}$ & -0.04 \\
Education & 0.04 & -0.04 & 0.06 & $-0.13^{* *}$ & -0.06 & 0.00 \\
Female & -0.05 & -0.09 & $-0.09^{*}$ & -0.09 & $0.12^{*}$ & -0.07 \\
Area & $-0.13^{* *}$ & -0.06 & 0.02 & $0.22^{* * *}$ & -0.06 & -0.01 \\
Water & 0.01 & 0.02 & -0.06 & 0.00 & $0.11^{*}$ & 0.03 \\
Forest $\%$ & -0.06 & $-0.11^{*}$ & $0.18^{* * *}$ & 0.05 & -0.07 & $0.39^{* * *}$ \\
Machine & -0.07 & $-0.15^{* * *}$ & $0.25^{* * *}$ & 0.14 & -0.06 & 0.04 \\
Govt. Credit & -0.03 & -0.06 & $0.11^{*}$ & 0.07 & -0.01 & $0.15^{* * *}$ \\
Govt. Assist & 0.08 & 0 & -0.05 & -0.04 & 0.08 & $0.27^{* * *}$ \\
Ag. Association & $0.1 *$ & -0.05 & $0.09^{*}$ & $-0.09 *$ & 0 & 0.06 \\
Defn. Title & -0.03 & -0.08 & 0.03 & 0.03 & $0.21^{* * *}$ & -0.09 \\
Origin-North & 1 & $-0.51^{* * *}$ & -0.3 & $-0.23^{* * *}$ & 0.07 & 0.06 \\
Origin-Northeast & $-0.51^{* * *}$ & 1 & $-0.16^{* * *}$ & $-0.12^{* *}$ & $0.15^{* * *}$ & -0.03 \\
Origin-South & -0.3 & $-0.16^{* * *}$ & 1 & -0.07 & $-0.21^{* * *}$ & -0.01 \\
Origin-Southeast & $-0.23^{* * *}$ & $-0.12^{* *}$ & -0.07 & 1 & $-0.12^{*}$ & -0.09 \\
Residence Time & 0.07 & $0.15^{* * *}$ & $-0.21^{* * *}$ & $-0.12^{*}$ & 1 & $-0.18^{* * *}$ \\
Distance to Town & 0.06 & -0.03 & -0.01 & -0.09 & $-0.18^{* * *}$ & 1 \\
\hline
\end{tabular}

Notes: Results represent Spearman's rank correlation coefficients. * indicates a significant bivariate correlation at the $95 \%$ level, $* *=99 \%$, and $* * *=99.9 \%$. 
Table A3.2: Tukey tests for per hectare farm income by land use

\begin{tabular}{ll}
\hline & Difference (US\$) \\
\hline \hline Specialty $>$ Other-Livestock & $3,109^{* * *}$ \\
Specialty $>$ Cattle & $3,054^{* * *}$ \\
Specialty $>$ Cattle-Crop & $2,786^{* * *}$ \\
Specialty $>$ Soy & $2,246^{* * *}$ \\
Specialty $>$ Mixed-Crop & $1,848^{* *}$ \\
Specialty $>$ Staple & $1,551^{* *}$ \\
Staple $>$ Other-Livestock & $1,558^{*}$ \\
Staple $>$ Cattle & $1,503^{* * *}$ \\
Staple $>$ Cattle-Crop & $1,234^{*}$ \\
Mixed Crop $>$ Cattle & $1,206^{*}$ \\
\hline Notes: One-way ANOVA comparing the effect of land use on \\
income, p $<0.0001$, df $=6$, F= 12.2. \# of observations $=420$. \\
Only significant results reported.
\end{tabular}

Table A3.3: Per hectare farm income by land use

\begin{tabular}{lrr}
\hline & $\begin{array}{c}\text { Mean } \\
\text { (US\$) }\end{array}$ & \multicolumn{1}{c}{ SD } \\
& US\$) \\
\hline \hline Other-Livestock $(n=22)$ & 195 & 198 \\
Cattle $(n=134)$ & 250 & 1,202 \\
Cattle-Crop $(n=33)$ & 518 & 872 \\
Soy $(n=21)$ & 1,002 & 477 \\
Mixed-Crop $(n=48)$ & 1,456 & 2,619 \\
Staple $(n=135)$ & 1,753 & 2,317 \\
Specialty $(n=27)$ & 3,304 & 4,585
\end{tabular}

Table A3.4: Correlation table between perceived overall life quality and other measures of satisfaction

\begin{tabular}{|l|l|l|l|l|l|l|l|}
\hline $\begin{array}{l}\text { Rural work } \\
\text { quality }\end{array}$ & $\begin{array}{l}\text { Urban work } \\
\text { quality }\end{array}$ & Transportation & $\begin{array}{l}\text { Cultural } \\
\text { activities }\end{array}$ & Education & $\begin{array}{l}\text { Health } \\
\text { services }\end{array}$ & Neighbors & Safety \\
\hline $0.22 * * *$ & $0.13 * * *$ & $0.31 * * *$ & $0.15 * * *$ & 0.00 & $0.16 * * *$ & $0.18 * * *$ & $0.29 * * *$ \\
\hline
\end{tabular}


Table A3.5 Additional results for ordered logit subjective wellbeing model

\begin{tabular}{|c|c|c|c|c|}
\hline Model & I & II & III & IV \\
\hline \multicolumn{5}{|l|}{ Other Satisfaction Measures } \\
\hline Safety & $0.87 * * *$ & -- & -- & -- \\
\hline Neighbors & $0.77 *$ & -- & -- & -- \\
\hline Transportation & $0.43 *$ & -- & -- & -- \\
\hline \multicolumn{5}{|l|}{ Monetary Outcomes } \\
\hline Farm Expenditures & -0.52 & -- & -- & -- \\
\hline Farm Income & -0.43 & -0.37 & -- & -- \\
\hline Forest Income & 0.58 & 1.09 & -- & -- \\
\hline Off-farm Income & -0.12 & -0.08 & -- & -- \\
\hline Income Diversity & -- & -- & -- & -- \\
\hline \multicolumn{5}{|l|}{ Land Use } \\
\hline Cattle & -0.36 & -0.26 & -0.35 & -- \\
\hline Cattle-Crop & 0.46 & 0.79 & 0.69 & -- \\
\hline Mixed-Crop & $1.59 *$ & $1.35^{*}$ & $1.09 \dagger$ & -- \\
\hline Staples & -0.02 & 0.14 & 0.09 & -- \\
\hline Soy & 0.92 & 0.95 & 0.36 & -- \\
\hline Specialty & 0.14 & 0.22 & 0.15 & -- \\
\hline \multicolumn{5}{|l|}{ Household Attributes } \\
\hline Family Labor & -0.03 & -0.02 & -0.01 & 0.01 \\
\hline Education & -0.13 & -0.01 & 0.00 & -0.01 \\
\hline Female & -0.58 & -0.48 & -0.50 & -0.53 \\
\hline Any Machinery & 0.20 & 0.12 & 0.10 & 0.14 \\
\hline Farm Size & 1.22 & $1.03 \dagger$ & 0.53 & 0.41 \\
\hline Water Access & -0.49 & -0.22 & -0.17 & -0.06 \\
\hline Forest Area & $-0.34 *$ & $-0.29 \dagger$ & $-0.29 \dagger$ & -0.20 \\
\hline Govt. Credit & 0.09 & -0.08 & -0.09 & -0.13 \\
\hline Govt. Extension & 0.21 & 0.14 & 0.16 & 0.18 \\
\hline Agric. Association & 0.09 & 0.10 & 0.10 & 0.12 \\
\hline Definitive Land Title & -0.26 & -0.23 & -0.3 & -0.24 \\
\hline Origin - Northeast & 0.23 & 0.5 & 0.49 & 0.43 \\
\hline Origin - South & -0.35 & -0.23 & -0.24 & 0.02 \\
\hline Origin - Southeast & 0.62 & 0.62 & 0.69 & 0.45 \\
\hline Residence Time & 0.22 & 0.26 & 0.24 & 0.25 \\
\hline Distance to Town & -0.01 & $-0.02 *$ & $-0.01 \dagger$ & $-0.02 * *$ \\
\hline Santarém & 0.40 & $0.53 \dagger$ & $0.54 \dagger$ & $0.50 \dagger$ \\
\hline AIC & 472 & 507 & 504 & 501 \\
\hline Log-likelihood & -203.80 & -225.47 & -226.90 & -231.55 \\
\hline \multicolumn{5}{|c|}{$\begin{array}{l}\text { Notes: Results presented in the table are the regression coefficients resulting from } \\
\text { variations of equation } 2 \text {, which relates perceived life quality to other satisfaction measures, } \\
\text { income, land use, and household attributes. It is a supplement to Table } 3 \text { in the main text. } \\
\text { Model I includes farm expenditures as an additional explanatory factor, model II excludes } \\
\text { other satisfaction metrics, model III excludes income, and model IV excludes land use. } \mathrm{n}= \\
328 ; \dagger \text { indicates significance at the } 90 \% \text { level, } *=95 \% \text { level, } * *=99 \% \text {, and } * * *=99.9 \% \text {. }\end{array}$} \\
\hline
\end{tabular}

